\title{
How important are local knowledge spillovers of public R\&D and what drives them?
}

\author{
Leonie Koch ${ }^{\mathrm{a}}$, Martin Simmler ${ }^{\mathrm{b}, \mathrm{c}, *}$ \\ ${ }^{a}$ University of Munich, Schackstrasse 4, 80539 Munich, Germany \\ ${ }^{b}$ Oxford University Centre for Business Taxation, Park End Street, OX11 HP Oxford, UK \\ ${ }^{c}$ German Institute for Economic Research Berlin, Mohrenstrasse 58, 10117 Berlin, Germany
}

\begin{abstract}
This paper analyzes the magnitude of local knowledge spillovers of public R\&D in Germany and its determinants using patent application data. We identify three distinct transmission channels. First, firms file more patent applications when collaborating with (local) public institutions. Second, firms file more patent applications when citing a public patent. Third, local public R\&D seems to increase the number of patent applications by local firms also via non-specific knowledge spillovers. Using a fixed effect instrumental variable regression approach, we find evidence for substantial local spillovers and that these are driven by non-specific knowledge spillovers.
\end{abstract}

Keywords: R\&D, university, research institute, public spending

JEL: I23, O34, O38

\section{Introduction}

There is a clear consensus that stimulating firm $R \& D$ is welfare increasing due to positive externalities and uncertainty (Arrow, 1962; Nelson, 1959), but the question about the most efficient way is still open to debate. In principle, there are two ways to do so. First, governments can stimulate private R\&D by increasing the profitability of R\&D investment, either by handing out cash payments or by providing

\footnotetext{
*Corresponding author

Email addresses: leonie.koch@econ.lmu.de (Leonie Koch), martin.simmler@sbs.ox.ac.uk (Martin Simmler)
} 
a beneficial tax treatment. Second, governments can fund public R\&D, which may stimulate firm R\&D via local knowledge spillovers which are driven by personal interactions and workforce mobility. While a large body of literature has examined the impact of direct subsidies ${ }^{1}$, empirical evidence on the magnitude of local knowledge spillovers of public on firm R\&D and its determinants is limited and largely based on universities. Universities engage, however, in both, knowledge as well as "degree" production. Identifying the transmission channel at work is thus challenging. Since communication and travel costs have substantially fallen over the last decades, technological spillovers are less and less bounded by national borders (Griffith et al., 2011) and local knowledge spillovers are a promising channel to solely support domestic firm R\&D. To inform policy makers on whether public R\&D should be part of the optimal firm R\&D support strategy or not, our paper aims to quantify the magnitude of local knowledge spillovers of public R\&D as well as its determinants by using patent, firm and county level data for Germany between 1995 and 2015 and exploiting regional variation in public $R \& D$ undertaken by (publicly funded) research institutes and universities.

We believe that Germany provides an excellent set-up for our research question. First, Germany relies substantially on public R\&D carried out by independent research institutes. Figure 1 illustrates the international comparison. While Germany, Japan, the UK, the US and the average EU 28 country have similar R\&D expenditures relative to GDP in the higher education sector, R\&D spending in the government sector (including the research institutes) is highest in Germany among the selected countries. Second, the German firm R\&D support strategy mainly consisted of funding public R\&D during our sample period. ${ }^{2}$ Germany did not offer

\footnotetext{
${ }^{1}$ See David et al. (2000) and Zúñiga-Vicente et al. (2014) for a literature review on the impact of cash subsidies on firm R\&D and Hall and Van Reenen (2000) and Guceri and Liu (2019) for a literature review on the impact of $\mathrm{R} \& \mathrm{D}$ tax credits on firm $\mathrm{R} \& \mathrm{D}$. In general, prior literature has found that $R \& D$ tax credits are quite successful in stimulating firm $R \& D$ (e.g. Lokshin and Mohnen, 2012; Mulkay and Mairesse, 2013; Rao, 2016; Dechezlepretre et al., 2016; Guceri, 2018), while cash subsidies increase firm $\mathrm{R} \& \mathrm{D}$ in particular for smaller and younger firms (e.g. Bronzini and Iachini, 2014; Howell, 2017).

${ }^{2}$ Germany introduced a R\&D tax credit in 2019.
} 
super-deductions for $R \& D$ expenditures or a lower tax rate on returns from $R \& D$ investment in the form of a patent box as introduced in several European countries over the last two decades (see, for example, Alstadsaeter et al., 2018). ${ }^{3}$ Thus, our focus on Germany mitigates concerns that the estimated spillovers of public R\&D are driven by both, public R\&D as well as generous direct subsidies. Third, German firms have comparably high $R \& D$ expenditures (see Figure 1). Thus, a no impact result cannot be explained by a generally low R\&D intensity of firms.

Figure 1: Public and Private R\&D Expenditure as a Percentage of GDP

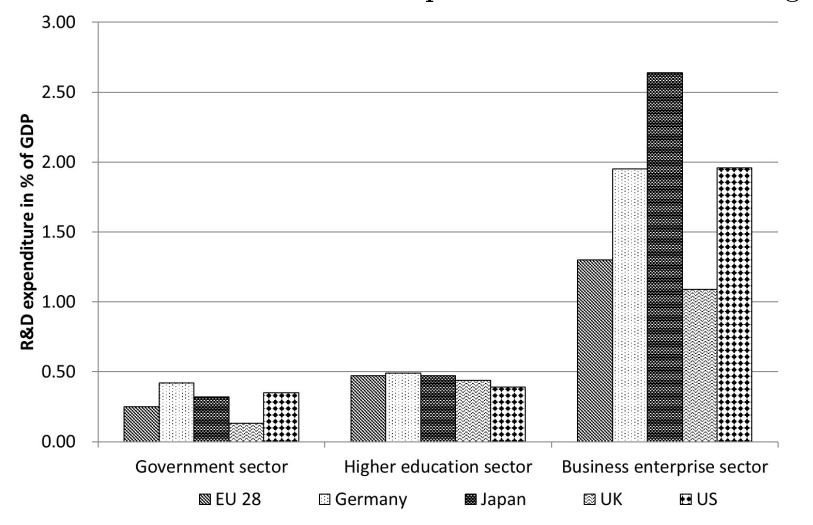

Source: Authors' calculations based on data from Eurostat, 2014.

Our paper consists of two empirical parts. In the first part we aim to quantify the relative importance of three potential local public knowledge spillover channels. The first channel is firms' use of specific knowledge that is produced by a local public institution (e.g. public patent). It is based on the idea that public institutions advance (fundamental) scientific knowledge and that this has positive (technological) spillovers to applied researchers (e.g. Foray and Lissoni, 2010). Prior work has shown that geographic proximity enhances these technological spillovers (e.g. Belenzon and Schankerman, 2013), which is consistent with the argument that (public) knowledge

\footnotetext{
${ }^{3}$ Patent box regimes grant preferential tax treatment for corporate income derived from intellectual property (IP), especially patented inventions. Firms can declare the profits derived from IP and these profits are taxed at a lower rate relative to income derived from standard business activities. The design of patent box regimes differs with respect to e.g. the tax rate, the type of eligible IP, income or expenses across countries.
} 
has a tacit dimension and thus cannot be fully transmitted via written publications. The second channel is the collaboration (or joint ventures) of firms with (local) public institutions. This channel acknowledges that firms may not only use public knowledge but also work together with public institutions towards creating new knowledge. Firms benefit from collaboration as it allows them to access knowledge as well as technology of public institutions and to exploit synergy effects as, for example, documented for research consortiums in Japan (Branstetter and Sakakibara, 2002). Prior work has shown that geographic proximity amplifies the likelihood of collaborations, potentially, as face-to-face interactions are still the preferred mode of communication (e.g. Rybnicek and Königsgruber, 2019). The third channel is the use of non-specific public knowledge by local firms. This channel is motivated by the fact that innovation is a complex process, which consists of "weaving different types of knowledge into something new, different and unprecedented that has economic value" (Feldman and Kogler, 2010, p. 384). In particular, new technologies do not emerge fully developed overnight but are rather fine-tuned over time. Existing local knowledge is likely to be key for the gradual adjustments as it is easily available to the entrepreneurs. While this knowledge includes the outcome of prior public R\&D, it also includes the knowledge about the underlying process of these innovations, e.g. "the knowledge of what does not work, what approaches have been tried, and led to dead ends" (Feldman and Kogler, 2010, p. 386). Since in particular the latter knowledge is highly tacit and entrepreneurs rely on existing local knowledge for the full development, formal or informal personal interactions (e.g. consulting projects) as well as workforce mobility are likely to be imperative for the transmission of it. ${ }^{4}$

To analyze the importance of the different spillover channels, we exploit regional variation in public R\&D in Germany between 1995 and 2015. We proxy firm R\&D with the number of patent applications and technological spillovers by using patent citation data. Collaboration spillovers are proxied by joint patent applications of

\footnotetext{
${ }^{4}$ The existence of these non-specific knowledge spillovers may also explain why substantial local public knowledge spillovers and public knowledge tacitness do not contradict each other (see Foray and Lissoni, 2010, p. 293): Non-specific public knowledge is not tacit because of the novelty or the strategy of the producers but as it is (usually) not included in written publications.
} 
firms and public institutions. Lastly, we proxy non-specific knowledge spillovers with the number of public patent applications within a region.

To assess the relevance of the three channels, we estimate count models of patent applications on the applicant-region level. To account for public R\&D quality in our analysis, we use citation data to understand which public R\&D, e.g. what type of public patents, is of higher relevance for local firm R\&D, as measured by the number of citations by corporate patents. Moreover, we investigate whether public patents that are more relevant for local firm R\&D cite more local firm patents to assess the role of reverse causality. Based on the results of the transmission channel analysis and using the characteristics of the average public patent (and taking into account that we capture only part of all collaborations) allows us then to quantify the relative importance of the different local knowledge spillovers channels. To deepen our understanding further, we estimate not only the direct effect on affected firms but also spillovers into other regions. Furthermore, we assess the evidence for impact heterogeneity related to the type of affected firm (low vs. high R\&D intensity firms, measured by the number of patent applications filed before our sample period) as well as the type of corporate patent (low vs. high technological value, measured by the number of patent classes).

In the second part of the empirical analysis, we aim to quantify the overall magnitude of local knowledge spillovers of public R\&D on local firm R\&D within a county. We proxy public and firm R\&D with the number of patent applications and use an instrumental variable (IV) strategy to account for a potential bias in the OLS estimator due to measurement error, omitted variables and reverse causality. The excluded instrument we employ is the 4-year lagged institutional funding for research institutes.

Three aspects are worth highlighting with regard to our analysis. First, we do not aim to quantify the overall magnitude of knowledge spillovers of public R\&D, but only the magnitude of local knowledge spillovers and the underlying channels at work. We believe these two dimensions to be crucial to understand to what extent public R\&D should be used to stimulate firm R\&D as (national) governments care only about firms that undertake research in their region (country). Since communi- 
cation and travel costs have substantially fallen over the last decades, technological spillovers of public R\&D are less and less bounded by national borders (Griffith et al., 2011), which means that local knowledge spillovers are potentially a key transmission channel for stimulating predominantly domestic firm R\&D. Given our focus, we implement a relatively simple approach to capture local spillovers. In particular, we do not use a distance based approach as in Alcacer and Gittelman (2006) or Lychagin et al. (2016) but focus on spillovers within a county, which has in Germany an average size of around 1,000 square kilometers. This level of analysis is likely to capture a large part of local knowledge spillovers given the results of prior literature (e.g. Andersson et al., 2009; Belenzon and Schankerman, 2013) and provides us with enough variation to assess the overall magnitude of local knowledge spillovers. Second, we focus on local knowledge spillovers. To remove time-invariant heterogeneity which could bias our estimates, we include region-fixed effects in all specifications. This means, however, that time-invariant effects of public institutions, e.g. related to the (unchanged) provision of $R \& D$ research infrastructure (e.g. facilities, resources, and services) or the provision of consultancy (see Ankrah and AL-Tabbaa, 2015) are absorbed as well if they are unrelated to the knowledge production dimension of public R\&D. ${ }^{5}$ Third, local knowledge spillovers may include product market rivalry spillovers, e.g. negative spillovers that result from the competition of firms/producers in product markets (see Branstetter and Sakakibara, 2002; Bloom et al., 2013). ${ }^{6}$ Their importance is, however, likely to be limited as public R\&D producers compete with private firms in only very few markets, most important are probably the market for contract research and for technical testing and analysis (e.g. metrology services). Moreover, the market share of public R\&D producers in these markets is suggested to be small. The research institutes that belong to one of the four main

\footnotetext{
${ }^{5}$ For example, if local public R\&D affects firm $R \& D$ via the pure provision of research facilities and the provision is unrelated to public knowledge production, this would not be captured by our estimation strategy. If, however, public knowledge production increases the value of using public research facilities by local firms, we would capture the second effect partly as well.

${ }^{6}$ In addition, public R\&D may, by supporting or setting standards in a particular industry, influence product market competition between firms in this industry.
} 
research organization considered in our analysis had in 2010 own business income (e.g. turnover) of around 1.2 billion EURO (see Table 1), while overall turnover in the sectors scientific research and development (NACE Rev. 2 Code 72) and technical testing and analysis (NACE Rev. 2 Code 71.2) amounted to 10 and 9 billion EURO in Germany in 2010, respectively. ${ }^{7}$

The data of our empirical analysis is - as already indicated - patent application and citation data. We choose this data as it allows an (also imperfect) approximation of the three channels outlined above. Moreover, it has the benefit that we are able to study the patenting behavior of all firms in Germany which would not be the case when using financial statements data (and R\&D expenses). The downside is that we only observe patent applications. As pointed out by Griliches (1998), this means that we potentially underestimate the extent of local knowledge spillovers since not all inventions are patentable and not all new innovations are patented. We address this concern by using the number of firm R\&D employees as an alternative measure for firm R\&D. Since this information is only observed on the county level, the heterogeneity results (which firms and patents benefit most from public R\&D) should be interpreted with some caution as firms' propensity to "patent" varies between industries as well as with firm size (Scherer, 1983; Bound et al., 1984). Moreover, we apply an IV strategy to address the measurement error in the number of public patents.

The patent data we use stems from the OECD RegPat and Citation database and covers all patents that are filed with the European Patent Office (EPO) and under the Patent Co-operation Treaty (PCT). It includes information on general patent characteristics, address information for inventors and applicants as well as citations of patent and non-patent literature. The home address of inventors is key for our analysis as we use it for the geographical mapping of patents. It allows a better approximation of where $R \& D$ takes place than using the location of the applicant (see, for example, Lychagin et al., 2016). The latter would in particular be misleading

\footnotetext{
${ }^{7}$ Federal Statistical Office, Table 47415-009 (http://www.datenportal.bmbf.de/portal/de/ K16.html, last accessed 16/04/2020).
} 
for large firms that consist of several establishments or for legally non-independent research institutes as for example the Fraunhofer institutes, for which the applicant is always the Fraunhofer Society located in Munich.

We obtain three main results from our empirical analysis. First, we find evidence that is consistent with the existence of all three types of spillovers. Based on the assumption that we are able to identify causal effects and that the proxies employed capture reasonably well the three different channels, our results suggest that the non-specific knowledge spillovers are most important as they account for around $2 / 3$ of the overall local knowledge spillovers of public R\&D. Moreover, we find that the non-specific knowledge spillovers are in particular relevant for low $R \& D$ intensity firms, which is consistent with the argument that non-specific knowledge is highly tacit and that tacit knowledge is in particular relevant for firms in their early stages (see Feldman and Kogler, 2010). However, there is no difference between the channels with regard to what sort of public R\&D matters the most (high quality public R\&D) and which firm patents are affected the most (low quality firm R\&D).

Second, assuming that our IV strategy allows a causal interpretation of the results and that the number of public patents is a reasonable proxy for public R\&D production, we find evidence for substantial local knowledge spillovers of public R\&D. For the median county, our estimates imply that one additional public patent generates around 3 additional firm patents. Consistent with the results of the transmission channels, we find that these additional corporate patents come from low R\&D intensity firms. Since we do not find evidence that firms that benefit from local R\&D in one county file less patent applications in other counties, our result suggests that local public $R \& D$ is an efficient way to stimulate (local) firm $R \& D$. Using the average costs per EPO patent application (for UK firms) as reported by Dechezlepretre et al. (2016), our estimates imply public costs per additional firm patent of around 1.4 million EURO. This is less than $2 / 3$ of the implied public costs for one firm patent application in the US or the UK using R\&D tax credits as firm R\&D support strategy (see Dechezlepretre et al., 2016; Rao, 2016).

Third, based on our estimation strategy and the proxies employed, we find that the local knowledge spillovers of public $R \& D$ on local firm $R \& D$ are increasing at a 
decreasing rate in the level of public $R \& D$. While we are able to show that this effect is not driven by a potential correlation of region size with the level of public patents or a smaller number of low R\&D intensity firms in regions with a large number of public patents, we are not able to explain empirically why the relationship is nonlinear. Theoretically, there are at least three potential explanations. First, the relevant non-specific knowledge created by additional public R\&D could be decreasing in the level of public R\&D. Second, public knowledge production could have diminishing returns as there may be only a limited number of firms within a region that can benefit from public R\&D. Third, public and firm R\&D producers may compete in local labor markets. In this case, more public R\&D does not only lead to larger local knowledge spillovers, but also to higher wages for R\&D employees (due to the demand effect) and the latter effect dampens the former. ${ }^{8}$

Our work contributes to the literature on local knowledge spillovers of public R\&D in several ways. First, we provide evidence in line with various other studies on positive local knowledge spillovers of public R\&D. The seminal paper in this field is Jaffe (1989). Using US state level data, he finds an elasticity of corporate patents to university R\&D expenditure of around 0.1. Andersson et al. (2009) find that openings of higher education institutions in Sweden increased the number of patents in the same region. Belenzon and Schankerman (2013) find - using citation data - that spatial proximity matters not only for private knowledge as shown by Jaffe et al. (1993) and Audretsch and Feldman (1996), but also for the diffusion of public knowledge. Our analysis comes to the same conclusion, but also suggests that citation data is unlikely to capture the full extent of local knowledge spillovers since a substantial part of them (e.g. non-specific knowledge spillovers) cannot be traced with citation data. ${ }^{9}$

\footnotetext{
${ }^{8}$ Two additional channels that have been suggested in the literature are that public R\&D might directly replace private $R \& D$, if firms substitute public $R \& D$ for their own $R \& D$, and that public $\mathrm{R} \& \mathrm{D}$ could distort the competition between firms by funding some firms at the cost of others (see David et al., 2000; Zúñiga-Vicente et al., 2014, for a literature review).

${ }^{9}$ This problem may be less severe when using US patent data (which includes a more complete list of relevant existing patents), but is certainly true for EPO patent data as EPO patent applications must only contain the most relevant existing patents (see, for example, Maurseth and Verspagen
} 
Further, while most of the recent studies have used less aggregated data than Jaffe (1989), not all of them have addressed the potential endogeneity of public R\&D. The most convincing approach employed in prior literature is by Kantor and Whalley (2014). They exploit that US universities usually invest a fixed amount of their endowments' market value every year and instrument university spending with university endowment in combination with variation in stock market returns. Our instrument follows this rationale. While the 4-year lagged institutional funding may not be fully exogenous, it should be noted that reverse causality is likely to be of minor importance in Germany as institutional funding is determined not only by the hosting state but by all German states as well as the federal state. In line with the results by Kantor and Whalley (2014), we also find a substantial downward bias when ignoring the endogeneity of local public $R \& D$.

Second, we contribute to the literature that investigates heterogeneity of local knowledge spillovers of public R\&D. Link and Rees (1990) find that large firms are more likely to participate in university-based research but that small firms are better able to transfer the knowledge. Acs et al. (1994) report that the elasticity of innovative activity with respect to corporate $R \& D$ is greater for large firms and that the elasticity with respect to public $R \& D$ is greater for small firms. Moreover, the authors show that geographic proximity between universities and corporate R\&D has a larger impact on small firms. Our results for low (and likely small) and high R\&D intensity (and likely large) firms are in line with these findings.

Which type of public R\&D creates the largest spillovers has not yet been analyzed in great detail. Branstetter and Sakakibara (2002), who study the effectiveness of research consortiums in Japan, find that the more basic research (measured using survey data) is done by a consortium, the higher a firm's R\&D after its inclusion in the research consortium. Work by Cassiman et al. (2012) suggests that basic public $R \& D$ is of higher importance for firm $R \& D$ in the case of industry-university collaborations. Our results show that patents that have a wider scope (e.g. patents that are filed for more patent classes) are more important for collaboration, technologi-

$\overline{(2002) \text { and von Wartburg et al. (2005)) }}$. 
cal and non-specific knowledge spillovers. Moreover, our work suggests that patents with a wider scope receive more forward citations and thus are likely to have a higher technological value.

Our two sets of heterogeneity results have implications for the transmission channel at work. A common argument for the existence of local knowledge spillovers is that geographic closeness facilitates the interaction between firm and public institution R\&D employees, which allows them to learn from each others' research activities. Moreover, public knowledge may also be transferred to firms by employees that change jobs but are still employed in the same region (Almeida and Kogut, 1999) or by university spin-offs, which locate close to their source university to capture the competitive advantage of the provision of skilled labor, specialized facilities and expertise by the university (Bercovitz and Feldman, 2006). While our results highlight the relevance of non-specific knowledge spillovers and thus are in line with the communication channel, they raise the question why high R\&D intensity firms do not benefit from public R\&D. One potential explanation for this finding is that there may be two separate $R \& D$ employee markets, one for low R\&D intensity firms and public institutions and one for high R\&D intensity firms.

Our third contribution to the literature is that we provide robust evidence that it is indeed public knowledge production that affects local firm R\&D. One challenge regarding prior work is the identification of the driving force at work, as most of the studies focus on public R\&D carried out by universities. Universities engage, however, in both "degree" as well as R\&D production and both are likely to influence R\&D activities by firms. Disentangling these two effects is challenging, as it necessarily relies on a parameterization. Abel and Deitz (2011), who proxy "degree production" with the number of degrees per 100 working-age people and knowledge production by R\&D expenditures per enrolled student, find that it is the latter that increases local human capital since the impact of degree production is limited due to labor force mobility. Some of the results by Kantor and Whalley (2014) can be read in a similar vein. They find a larger effect of university $R \& D$ on wages in counties with universities that have a higher research intensity and in counties with industries that cite university patents more often. While this seems conclusive, it should be 
noted that degrees also have a quality dimension, which is likely to be influenced by a universities' knowledge production. We contribute to this stream of literature by applying an IV strategy that exploits variation in institutional funding of research institutes, which is substantially less related to "degree" production within a region compared to (institutional) funding for universities. ${ }^{10}$ Moreover, our result suggests that technological and collaboration spillovers only account for a small share of the overall local knowledge spillovers of public R\&D.

The rest of this article is structured as follows. In section 2 we explain the German research system. Section 3 describes the data used for our empirical analysis. Section 4 explains the methodology and reports the results for the transmission channels, and section 5 does this for the overall magnitude of local knowledge spillovers of public R\&D. Section 6 concludes.

\section{R\&D in the Public Sector in Germany}

Since launching of the Lisbon strategy in 2000, the EU member countries aim to invest $3 \%$ of GDP in R\&D. Compared to other EU countries, Germany is close to this target with a sum of public and private R\&D expenditures of $2.88 \%$ of GDP (based on 2014 data). Surprisingly, Germany is also one of the few EU countries that offered only cash subsidies to the private sector and did not grant tax credits for R\&D expenses or a lower tax rate on the return of $R \& D$ investment in the form of a patent box over our sample period. Instead the German federal and the state governments heavily invest in public R\&D carried out by independent research institutes and similar to other countries - fund universities, which also engage in R\&D activities. The majority of the independent research institutes belong to one of the following umbrella associations: the Max Planck Society, the Fraunhofer Society, the Leibniz

\footnotetext{
${ }^{10}$ Research institutes in Germany are not directly involved in the provision of higher education (except in the case of doctoral students). R\&D production of research institutes may, however, impact (nearby) universities' degree production indirectly via, for example, collaborations of research institutes and universities as well as personal ties between the two.
} 
Society and the Helmholtz Community. ${ }^{11}$ As shown in Figure 1, R\&D spending in the government sector (including the independent research institutes) is almost as high (12.5 billion EURO in 2014) as in the higher education sector (15.3 billion EURO).

Figure 2: Evolution of Public Patent Applications by Type of Applicant

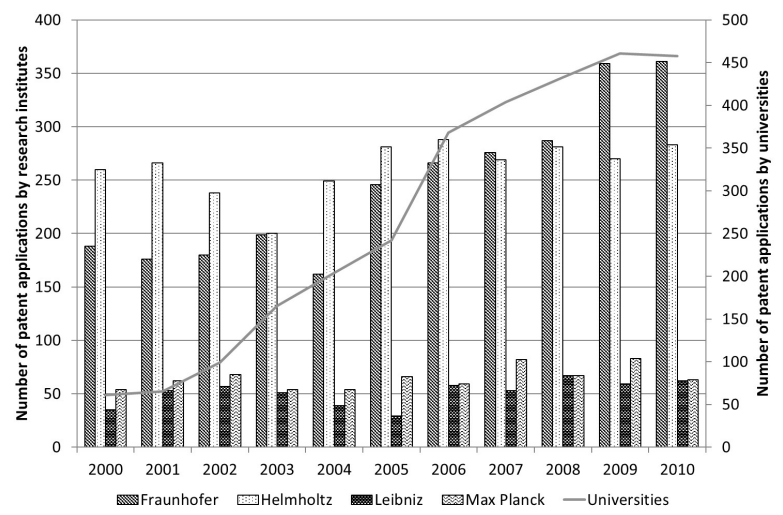

Notes: Patent applications include only applications filed with the European Patent Office or under the Patent Co-operation Treaty. Source: Authors' calculation based on OECD RegPAT database 2000-2010.

The structure of the higher education sector in Germany is as follows. Overall, there are more than 400 higher education institutes, but only about $25 \%$ of them are "real" universities (see also Table 1). The rest are universities of applied sciences (Fachhochschulen). They engage in research as well but do so to a much smaller extent and are usually highly specialized in one field. While the number of universities of applied sciences has increased over time, the number of universities has been stable. The state, in which the higher education institute is located, is responsible for $75 \%$ of the basic funding, which is usually a function of the number of students, the number of graduates and the amount of third party funding obtained. These criteria vary from state to state. The federal government and the private sector contribute in the form of public and private third party funding for specific research projects. Tuition fees are not a significant source of funding. The level of university R\&D expenditures

\footnotetext{
${ }^{11}$ Governmental research institutes exist in Germany as well, but they are of minor importance and conduct mainly departmental research for federal and state administration.
} 
has increased over our sample period, from 8.4 billion EURO in 2000 to 12.7 billion EURO in 2010. ${ }^{12}$ The main driver was an increase in third-party funding, which grew from 2.8 billion EURO (one fourth) in 2002 to 5.9 billion EURO (one half) in 2010. The number of university patent applications filed with the EPO or under the PCT also increased between 2000 to 2010 (see Figure 2). One factor which is likely to have contributed to the increase in university patent applications is a law change in 2002. Prior to 2002, professors and researchers at a university had "Professor's Privilege" which allowed them to file patents for their own inventions as the sole applicant. After the reform, universities were granted the intellectual property rights of their employees and the inventors received only a compensation for their discoveries. Employees at public research institutes never had these exclusive intellectual property rights to their inventions. ${ }^{13}$

The main players in the government sector are the research institutes that belong to one of the four research umbrella organizations named earlier. They account for roughly $75 \%$ of overall R\&D expenditures in the government sector in Germany. ${ }^{14} \mathrm{~A}$ large share of their income $(60 \%)$ comes from the federal and the state governments in the form of institutional funding. There is, however, substantial heterogeneity between organizations. Further, the reader should note that the federal structure in Germany is also visible in public R\&D funding as the state in which the institute is located does not bear the whole (state) burden, but all other states contribute to

\footnotetext{
${ }^{12}$ German Federal Ministry of Finance, Data portal, Table 1.6.2 (http://www.datenportal. bmbf.de/portal/de/K16.html, last accessed 16/04/2020).

${ }^{13}$ We believe the impact of the professor privilege for university staff until 2002 to be neglectable on our results. First, our sample for the analysis of the overall magnitude of local knowledge spillovers of public R\&D only includes the years from 2003 to 2010. Moreover, we apply an IV strategy based on the funding for research institutes which should account for any remaining measurement error. Second, while we use the years from 2000 to 2010 for the transmission channel analysis, the resulting measurement error is likely to be small as university patents account for at most $40 \%$ of the considered public patents (based on 2010 data) and there was only a university privilege in 3 out of 11 years during our sample period. Moreover, the characteristics of the average public patent application are largely independent of the sample period considered (e.g. 2005 to 2010 vs 1995 to 2010$)$.

${ }^{14}$ German Federal Statistical Office, 2012, Finance and Taxation (Fachserie 14), Reihe 3.6, Table 1.3 .
} 
the funding as well. ${ }^{15}$

Table 1: Funding and Spending of Public R\&D in 2010

\begin{tabular}{|c|c|c|c|c|c|c|}
\hline & $\begin{array}{c}\text { Higher } \\
\text { Education }\end{array}$ & Fraunhofer & $\begin{array}{c}\text { Max } \\
\text { Planck }\end{array}$ & Helmholtz & Leibniz & Other \\
\hline \# Institutions & $\begin{array}{c}415 \\
\text { (106 Uni.) }\end{array}$ & 60 & 75 & 17 & 86 &.$/$. \\
\hline Share fundamental research &.$/$ & 5 & 100 & 71 & 75 & 30 \\
\hline Share natural sciences & 30 & 30 & 83 & 52 & 57 & 27 \\
\hline Share engineering & 20 & 64 & 0 & 34 & 10 & 22 \\
\hline Share humanities & 22 & 2 & 11 & 1 & 20 & 31 \\
\hline $\begin{array}{l}\text { \# Overall patents } \\
\text { \# EPO and PCT patents }\end{array}$ & $\begin{array}{l}. / . \\
458\end{array}$ & $\begin{array}{l}502 \\
361\end{array}$ & $\begin{array}{l}87 \\
63\end{array}$ & $\begin{array}{c}\text { approx. } 400 \\
283\end{array}$ & $\begin{array}{l}\text { approx. } 110 \\
62\end{array}$ & \\
\hline $\begin{array}{l}\text { R\&D budget (€bn) } \\
\text { Institutional funding (€bn) } \\
\text { Own business income (€bn) }\end{array}$ & $\begin{array}{l}12.7 \\
6.8 \\
. /\end{array}$ & $\begin{array}{c}1.62 \\
0.55 \\
0.5\end{array}$ & $\begin{array}{l}1.54 \\
1.23 \\
0.07\end{array}$ & $\begin{array}{c}3.20 \\
2.04 \\
0.6\end{array}$ & $\begin{array}{l}1.41 \\
0.91 \\
0.01\end{array}$ & $\begin{array}{l}5.2 \\
. / \\
. /\end{array}$ \\
\hline $\begin{array}{l}\text { Institutional funding shares } \\
\text { Federal gov. } \\
\text { Home state gov. } \\
\text { Other state gov. }\end{array}$ & $\begin{array}{c}25 \\
75 \\
0\end{array}$ & $\begin{array}{c}90 \\
6.7 \\
3.3\end{array}$ & $\begin{array}{l}50 \\
25 \\
25\end{array}$ & $\begin{array}{c}90 \\
5 \\
5\end{array}$ & $\begin{array}{c}50 \\
25-50 \\
50-75\end{array}$ & $\begin{array}{l}. / . \\
. / \\
. / .\end{array}$ \\
\hline
\end{tabular}

Notes: Federal and state funding shares are on average. Contribution of other states depends on Koenigsteiner Schluessel. Patent applications include only applications filed with the European Patent Office or under the Patent Co-operation Treaty. Humanities include social sciences. Source: Authors' calculations based on German Federal Ministry of Finance, data portal, Table 1.6.1 and 1.2.2, German Statistical Office, 2012, Finance and Taxes (Fachserie 14), Reihe 3.6, Table 2.4, 3.8, 4; GWK - Pakt fuer Forschung und Innovation - Monitoring-Bericht 2018, Table 14, and OECD RegPat database, 2010.

The Fraunhofer Society (17,000 employees) consists of 60 legally non-independent institutes (in 2010) and is the largest organization for application-oriented research in Europe. Two thirds of their R\&D expenditures comes from project funding or own income which is relatively high compared to the other research organizations, the remainder is institutional funding. The latter comes to $90 \%$ from the federal government, $3.3 \%$ from the "home" state and 6.6\% from all other states. In 2010, the overall budget of the Fraunhofer Society amounted to 1.62 billion EURO and the Fraunhofer institutes filed 361 patent applications with the EPO (or under PCT) in

\footnotetext{
${ }^{15}$ The contribution of all non-home states follows the Koenigsteiner Schluessel, which is based on tax revenue after fiscal equalization $(67 \%)$ and population size of the respective state $(33 \%)$.
} 
our data, out of a total of 502 patentable innovations in $2010 .^{16}$

Researchers at the 75 Max Planck institutes (13,000 employees) conduct solely fundamental research. The majority of the organization's expenditures (1.54 billion EURO in 2010) is institutionally funded (around 80\%) and stems equally from the federal government and the states. Half of the state share is funded by the "home" state and the rest by all other states. The Max Planck society registered 63 new patents with the EPO (or under the PCT) in our data and had in total 87 patent applications in 2010. ${ }^{17}$ The relatively high expenditures per filed patent compared to the Fraunhofer institutes is due to a stronger focus on natural sciences $(83 \%$ compared to $30 \%$ ), humanities (11\% compared to $2 \%$ ) and fundamental research (100\% compared to $5 \%$ ).

The Helmholtz Community (32,000 employees) is the biggest research organization in Germany and consists of 17 research centers. They conduct fundamental research $(71 \%)$ by employing large facilities. Institutional funding makes up around $75 \%$ of their total income (3.20 billion EURO in 2010) and public and private third party funding and own income around 25\%. The institutional share is borne to $90 \%$ by the federal government, $5 \%$ by the "home" state and the rest by all other states. The Helmholtz institutes filed around 400 new patent applications in 2010, 283 are observed in our data. ${ }^{18}$ While the ratio of expenditures per patent is closer to the one for the Fraunhofer institutes compared to the Max Planck institutes, it is still larger. The reason is the stronger focus on natural sciences $(52 \%)$ and fundamental research $(71 \%)$.

The Leibniz Society (13,500 employees) has 86 independent member institutions

\footnotetext{
${ }^{16} \mathrm{GWK}$ - Pakt fuer Forschung und Innovation - Monitoring-Bericht 2018, Table 14 (https://www.gwk-bonn.de/fileadmin/Redaktion/Dokumente/Papers/GWK-Heft-58_ Monitoring-Bericht-2018.pdf, last accessed 16/04/2020).

${ }^{17} \mathrm{GWK}$ - Pakt fuer Forschung und Innovation - Monitoring-Bericht 2018, Table 14 (https://www.gwk-bonn.de/fileadmin/Redaktion/Dokumente/Papers/GWK-Heft-58_ Monitoring-Bericht-2018.pdf, last accessed 16/04/2020).

${ }^{18} \mathrm{No}$ exact number is available for 2010. In 2012, 409 patents have been filed. (GWK - Pakt fuer Forschung und Innovation - Monitoring-Bericht 2018, Table 14 (https://www.gwk-bonn.de/ fileadmin/Redaktion/Dokumente/Papers/GWK-Heft-58_Monitoring-Bericht-2018.pdf, last accessed 16/04/2020)).
} 
that widely vary from academic service facilities to fundamental research institutes. Around $65 \%$ of their budget (1.41 billion EURO in 2010) is institutionally funded. Half of the institutional funding comes from the federal government, and on average $25 \%$ from the "home" and 25\% from all other states, but this varies between institutes. The member institutions of the Leibniz society filed 66 patent applications in our data, out of around 110 in total in 2010. ${ }^{19}$ The relatively higher expenditures per filed patent result from a larger budget share for natural science (55\%), humanities $(20 \%)$ and for fundamental research $(75 \%)$.

The funding for the research institutes is set for some years in advance in nonpublic committees, in which representatives of the umbrella organizations as well as of the federal and state governments take part. Institutional as well as overall funding increased over time, the latter from 5.4 billion EURO in 2002 to 7.8 billion EURO in 2010. Consistent with the budget increase, an upward trend in the number of patent applications by these research institutes in our data is observed between 2000 and 2010 (see Figure 2). Figure 3 summarizes the evolution of the overall number of patent applications by universities and our considered research institutes. Further, the figure shows the evolution of private patents, which also increased between 2000 and 2010 (although with a substantial drop during the financial crisis).

\section{Patent Data}

In the following, we describe the data used for our empirical analysis. All patent data stems from the OECD RegPat (Update March 2018) and Citation database (Update September 2017). ${ }^{20}$ This database covers all patent applications filed with the European Patent Office (EPO) and under the Patent Co-operation Treaty (PCT) up to 2015 and includes general information about the patent as well as name, address

\footnotetext{
${ }^{19}$ No exact number is available for 2010 . In 2012, 121 patents have been filed (GWK - Pakt fuer Forschung und Innovation - Monitoring-Bericht 2018, Table 14 (https://www.gwk-bonn.de/ fileadmin/Redaktion/Dokumente/Papers/GWK-Heft-58_Monitoring-Bericht-2018.pdf, last accessed 16/04/2020)).

${ }^{20}$ http: //www . oecd.org/sti/intellectual-property-statistics-and-analysis.htm
} 
Figure 3: Evolution of University, Research Institute and Firm Patent Applications

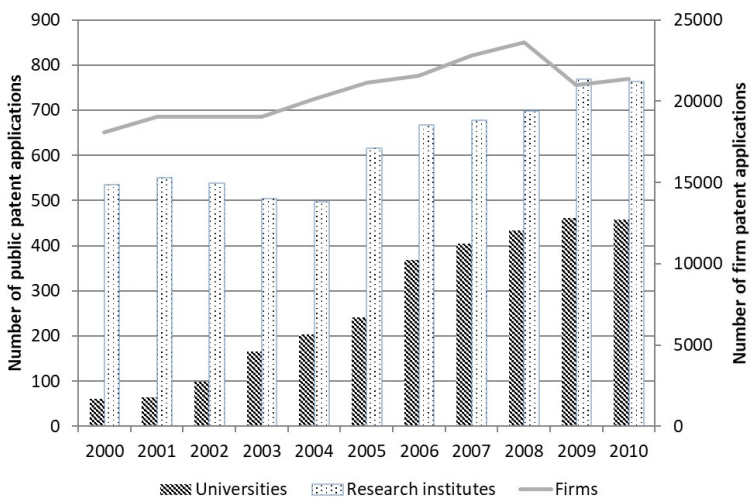

Notes: Patent applications include only applications filed with the European Patent Office or under the Patent Co-operation Treaty. Source: Authors' calculation based on OECD RegPAT database, 2000-2010.

and county codes of applicants and inventors. ${ }^{21}$ Moreover, information on patent and non-patent literature citations are available. ${ }^{22}$

We identified public institutions as the applicant by using the applicant names in the data (as well as the harmonized applicant names provided by the HAN database $\left.^{23}\right)$. Corporate applicants are identified via the legal form using the applicant names. Moreover, we also assumed a corporate applicant if the harmonized name was available (and if we did not identify a public institution as the applicant). The reason is that the harmonized names are based on financial statements data and thus should only include applicants that are corporations. Lastly, we also assumed a corporate applicant if the applicant has filed more than 30 corporate patents. ${ }^{24}$ To

${ }^{21} \mathrm{~A}$ patent application filed under the PCT is similar to a patent application filed with the EPO. It allows to file one patent application to protect an invention in several (potentially all PCT contracting) states.

${ }^{22}$ Since EPO or PCT patents may be cited via their national counterparts, we used the equivalent data sets provided by the OCED to account for that in the citation analysis. Moreover, the reader should note that the citation data includes both, applicant as well as examiner citations, but each cited patent is only counted once.

${ }^{23} \mathrm{http}$ ://www.oecd.org/sti/intellectual-property-statistics-and-analysis.htm

${ }^{24}$ The impact of the second and third selection criteria are small as we obtain similar results using only the legal form of the applicant as selection criteria. 
map patents into regions, we use the inventors' address information as this has been shown to capture local knowledge spillovers much better than using the headquarter location (see, for example, Lychagin et al., 2016). ${ }^{25}$ For our study, this is in particular relevant for the Fraunhofer Society as well as the Max Planck society, which consists of legally non-independent institutes and thus the applicant location would always be the location of the Fraunhofer or the Max Planck society. The regional weight of a particular patent is based on the share of inventors that live in a particular region (in our case in a county). If a patent is filed by more than one applicant, we further weight the patent count by the number of applicants. Thus, a patent that is filed by two applicants, a public institution and a firm, and is invented by two inventors, one located in $\mathrm{A}$ and one located in $\mathrm{B}$, has a regional public patent weight of 0.25 in $\mathrm{A}$ and of 0.25 in $\mathrm{B}$ and a regional corporate patent weight of 0.25 in $\mathrm{A}$ and of 0.25 in B. Figure 4 and Figure 5 illustrate the resulting distribution of public as well as firm patents in Germany in 2003. Counties with a darker color have more firm or public patent applications.

One potential disadvantage of our data is that it does not include all patents filed by firms, universities and research institutes. The resulting bias is, however, likely to be small. First, according to the German Patent Office, roughly 660.000 patents were valid in Germany in 2017, $80 \%$ of them were granted by the EPO. ${ }^{26}$ This is very comparable to the ratio of EPO and PCT patent applications to overall patents for the research institutes, reported in Table 1. Second, Dechezlepretre et al. (2016) show that the impact of the UK R\&D tax credit on the number of national and EPO patent applications is of similar magnitude.

\footnotetext{
${ }^{25}$ The use of the inventor address information is the main reason why we cannot use PATSTAT. While for some countries PATSTAT includes address information for inventors, it does not do so for Germany.

${ }^{26}$ Press notice of the German Patent Office (https://www.dpma.de/dpma/ veroeffentlichungen/statistiken/patente/index.html, last accessed 16/04/2020).
} 
Figure 4: Firm Patents in 2003

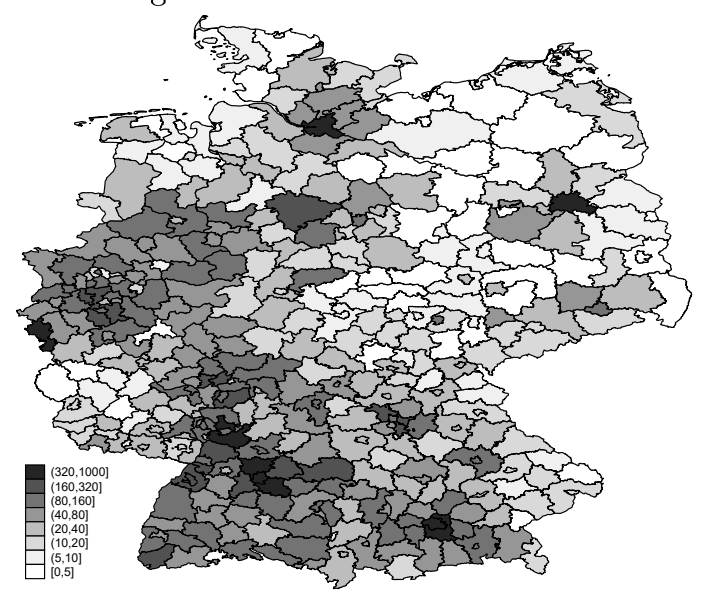

Notes: Figure shows the number of firm patent applications per county in 2003. Source: Authors' calculations based on OECD RegPat database, 2003.
Figure 5: Public Patents in 2003

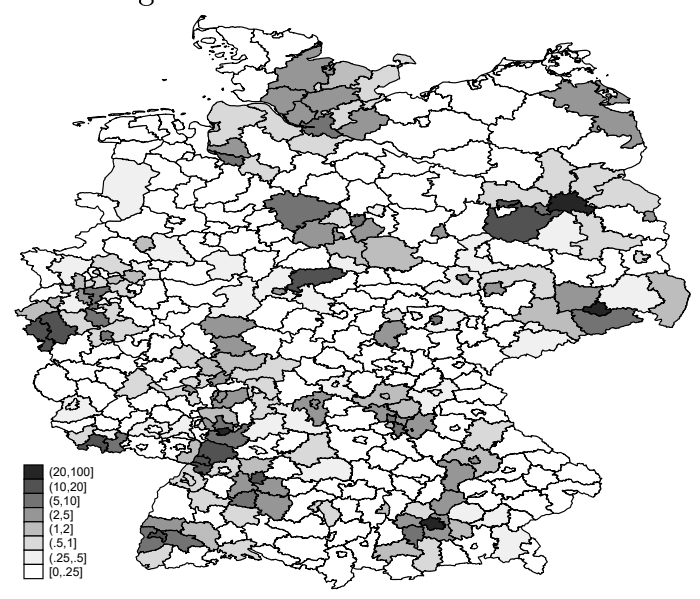

Notes: Figure shows the number of public patent applications per county in 2003. Source: Authors' calculations based on OECD RegPat database, 2003.

\section{Transmission Channels of Local Knowledge Spillovers of Public R\&D}

In the first part of the empirical analysis, we aim to quantify the relative magnitude of three different local public knowledge spillover transmission channels. Since this requires information about which public patents are relevant for firms, we start by investigating which observed public patent characteristics are a strong predictor for the number of (regional as well as non-regional) forward citations received, which is the most prominent measure for the technological value of a patent (see, for example, Trajtenberg et al., 1997). Moreover, we use the citation data to assess the role of reverse causality for local public R\&D with respect to local firm R\&D.

\subsection{Citation Data Analysis}

Methodology: To study the impact of public patent characteristics on the number of citations received by firm patents, we estimate a negative binomial regression model as it addresses the problem of overdispersion in the data (e.g. in the number of citations received by a public patent) explicitly compared to the Poisson model. Our estimation model reads as follows: 


$$
C_{i, r}=f\left(X_{i}, \lambda_{r}, \omega_{t}\right)+\epsilon_{i, r}
$$

The dependent variable is the number of forward citations $\left(C_{i, r}\right)$ of public patent $i$ received by corporate patents that are produced in the same region as the public patent $(r)$ and that cite the public patent within 5 years after publication of the public patent application. ${ }^{27}$ We include only citations by corporate patents (e.g. patents with at least one firm applicant) and weight the citation by the share of firm applicants. Moreover, we focus on citations within 5 years to avoid that older public patents have a higher likelihood of receiving more citations by definition (since they exist for longer). Since we have patent data up to 2015, our sample covers public patents with application dates between 1995 and 2010. ${ }^{28}$ To inform about differences of local and non-local technological spillovers, we construct also the number of nonregional citations by public patent $i$.

Our main explanatory variables of interest $\left(X_{i}\right)$ are whether the public patent has been developed jointly with a firm (which we assume to be the case if the patent has been filed jointly) as well as three (public) patent characteristics that have shown to matter in prior literature (although not necessarily consistently). These are the (i) number of backward patent citations, (ii) the number of backward non-patent citations as well as (iii) the scope of a patent, e.g. the number of patent classes a patent is filed for. Trajtenberg et al. (1997) report that university patents, which are supposedly more basic and thus are likely to have a higher technological value, have less backward patent citations and receive more forward citations. This is consistent with the argument that more backward citations indicate a more incremental innovation (Lanjouw and Schankerman, 2001). When using a regression approach, Trajtenberg

\footnotetext{
${ }^{27}$ We assume as outlined in Section 3 that a patent is produced in the same region if at least one inventor of the public patent lives in the same county as one inventor of the citing patent. Since inventors can live in different regions, a patent is not only produced in one region. We do not account for the strength of the regional link.

${ }^{28}$ We choose 1995 as the first year as universities and research institutes in East Germany had most likely completed their transmission process after the German re-unification.
} 
et al. (1997) find, however, a positive correlation of the number of backward and forward citations similar to Harhoff et al. (2003). The number of non-patent citations has not been used in many studies yet, but Cassiman et al. (2008) argue that these citations might indicate a more complex and fundamental knowledge. Thus, patents that cite more non-patent literature should receive a larger number of forward citations, which is supported by the results by Branstetter (2005). Lastly, patents with a wider scope have been found to increase firm value (Lerner, 1994), although they do not seem to have a higher monetary value (based on survey data) (Harhoff et al., 2003). Following prior literature, when entered into the regression, we scale all three measures by the maximum value of the respective variable in the same IPC class and year, and these measures are each labeled with the term "index" (see Table 2).

Our set of control variables includes time-fixed effects $\left(\omega_{t}\right.$, based on the application date of the cited public patent) and 3-digit IPC code (of the cited public patent) fixed effects in all regressions. In a sensitivity check, we also include main-inventor region-fixed effects $\left(\lambda_{r}\right) \cdot{ }^{29}$

Descriptive statistics for the full sample of public patents and the sample of public patents with at least one forward citation are shown in Table 2. The average (cited) public patent receives 0.03 (0.12) citations by regional firm patents and 0.49 (2.02) citations by non-regional firm patents within 5 years. While the absolute number of citations is low, the share of regional citations is with $6 \%$ substantial given that there are around 400 regions in Germany. Thus, the average regional share should - if all citations would come from within Germany and from all regions to the same extent - only amount to around $0.3 \%$. The relatively low number of forward citations can be explained as follows: First, we consider only forward citations within 5 years by firm patents. When including all citations, the average number of citations increases to 1.3 (3.3) per (cited) public patent. Second, the number of cited patents by the average EPO patent application is less than $1 / 3$ of the number of cited patents by the

\footnotetext{
${ }^{29}$ More precisely, we construct indicator variables for each region that are one if at least half of the inventors of a particular public patent are located in that region. When using dummy variables for each region in which at least one inventor is located, the model no longer converges.
} 
average US patent application (see Michel and Bettels, 2001). Harhoff et al. (2003) report that granted patent applications by German inventors in 1977 have been cited by 0.6 EPO patents on average over 20 years. Taking into account that the number of cited patents by EPO patent application has fallen over time (see Webb et al., 2005), the average number of forward citations in our sample seems even relatively high. Third, it should be noted that only a small subset of patents receives a large number of forward citations. This is not only in our sample the case, in which only one in every four public patents is at least cited once, but also on average (see OECD, 2015).

Comparing the average public patent and the average public patent that is cited at least once shows that the latter has slightly less backward citations (0.13 vs. 0.14), less non-patent citations ( 0.22 vs. 0.26$)$ and is filed for more patent classes ( 0.37 vs. 0.31). Moreover, the average public patent that is cited at least once is more likely to result from a collaboration with a firm (0.17 vs. 0.15$)$. The distribution of the main IPC class is, however, very similar.

Results: The results of the citation analysis are reported in Table 3. In the first three columns, the dependent variable is the number of regional citations. Col. (1) shows the results of our baseline specification which controls only for time and 3-digit IPC class fixed effects. In col. (2) we include time and main-inventor region-fixed effects. The results are very similar and suggest that public patents that are filed jointly with firms, with a larger number of backward patent citations and with a wider patent scope receive more forward citations. The number of backward non-patent citations does not matter. Since the number of backward patent citations could simply pick up an additional effect for joint venture public patents, we add interaction effects with the two (significant) patent characteristics and the indicator variable for joint venture public patents in col. (3). The result supports this presumption. While a wider patent scope increases the number of regional citations for all public patents, the number of backward patent citations matters only for joint venture patents.

To assess whether the two identified public patent characteristics matter only for regional or also for non-regional citations, we use the number of non-regional citations in col. (4) and the share of regional citations in col. (5) as dependent variable (and 
Table 2: Descriptive Statistics for Citation Data Estimation Sample

\begin{tabular}{lcccc}
\hline & \multicolumn{2}{c}{ All Public Patents } & \multicolumn{2}{c}{ Cited Public Patents } \\
& Mean & Median & Mean & Median \\
\hline \# Non-regional citations & 0.49 & 0.00 & 2.02 & 1.00 \\
\# Regional citations & 0.03 & 0.00 & 0.12 & 0.00 \\
Index PatentCitations (PatCit) & 0.14 & 0.00 & 0.13 & 0.00 \\
Index NonPatentCitations (Non-PatCit) & 0.26 & 0.00 & 0.22 & 0.00 \\
Index PatentClasses (PatClasses) & 0.31 & 0.27 & 0.37 & 0.27 \\
Joint Venture with Firm (JV) & 0.15 & 0.00 & 0.17 & 0.00 \\
Patent Class A & 0.15 & 0.00 & 0.14 & 0.00 \\
Patent Class B & 0.12 & 0.00 & 0.14 & 0.00 \\
Patent Class C & 0.27 & 0.00 & 0.28 & 0.00 \\
Patent Class D & 0.00 & 0.00 & 0.00 & 0.00 \\
Patent Class E & 0.01 & 0.00 & 0.01 & 0.00 \\
Patent Class F & 0.04 & 0.00 & 0.05 & 0.00 \\
Patent Class G & 0.24 & 0.00 & 0.21 & 0.00 \\
Patent Class H & 0.17 & 0.00 & 0.17 & 0.00 \\
D(Cited = 1) & 0.24 & 0.00 & 1.00 & 1.00 \\
\hline Observations & 11,468 & & 3,035 & \\
\hline
\end{tabular}

Notes: Table shows descriptive statistics for public patent applications filed between 1995 and 2010 with respect to their type as well as the number of citations they received within 5 years by corporate patents. PatCit stands for the number of backward patent citations, Non-PatCit for the number of backward non-patent citations and PatClasses for the number of IPC classes. The index variables are the normalized versions of the variables, dividing each variable by the maximum value of the respective variable in the same IPC class and year. Patents (and thus patent applications) are grouped into patent classes. The broad sections are A: human necessities; B: performing operations, transportation; C: chemistry, metallurgy; D: textiles, paper; E: fixed constructions; F: mechanical engineering, lighting, heating, weapons, blasting; G: physics and H: electricity. For more information see www.wipo.int/edocs / pubdocs/en/wipo_guide_ipc_2019.pdf (last accessed 16/04/2020). Source: Authors' calculations based on OECD RegPat and Citation database, 1995-2015.

an OLS estimator). While joint venture public patents increase in particular regional citations, public patents with a wider scope receive both, more regional as well as non-regional citations. Thus, two insights emerge from the analysis. First, the scope of a public patent is a reasonable proxy for its technological value, as measured by the number of forward citations. We will use it to account for the quality of patents. A second insight is that joint ventures have a substantial local dimension, which is consistent with prior work on industry-university collaborations (see, for example, the overview article by Rybnicek and Königsgruber, 2019).

We now investigate whether public patents that are of higher relevance for local firm R\&D build more strongly on local firm knowledge. The methodology is the same 
Table 3: Results for Number of Citations OF Public Patents

\begin{tabular}{|c|c|c|c|c|c|}
\hline \multirow{3}{*}{$\begin{array}{l}\text { Model } \\
\text { Dep. Var. }\end{array}$} & \multicolumn{4}{|c|}{ Negative Binomial } & \multirow{3}{*}{$\begin{array}{c}\text { OLS } \\
\begin{array}{c}\text { Share Regional } \\
\text { Citations }\end{array} \\
(5)\end{array}$} \\
\hline & \multicolumn{3}{|c|}{$\begin{array}{c}\text { \# Regional } \\
\text { Citations }\end{array}$} & \multirow{2}{*}{$\begin{array}{c}\text { \# Non-Regional } \\
\text { Citations }\end{array}$} & \\
\hline & (1) & $(2)$ & $(3)$ & & \\
\hline Index PatCit & $\begin{array}{c}0.595^{* *} \\
(0.239)\end{array}$ & $\begin{array}{c}0.608 * * \\
(0.263)\end{array}$ & $\begin{array}{l}-0.035 \\
(0.325)\end{array}$ & $\begin{array}{c}-0.307^{* *} \\
(0.156)\end{array}$ & $\begin{array}{c}0.048^{* *} \\
(0.023)\end{array}$ \\
\hline Index Non-PatCit & $\begin{array}{l}-0.056 \\
(0.175)\end{array}$ & $\begin{array}{l}-0.103 \\
(0.168)\end{array}$ & $\begin{array}{l}-0.038 \\
(0.163)\end{array}$ & $\begin{array}{l}-0.169^{*} \\
(0.102)\end{array}$ & $\begin{array}{c}0.010 \\
(0.014)\end{array}$ \\
\hline Index PatClasses & $\begin{array}{c}0.654^{* *} \\
(0.277)\end{array}$ & $\begin{array}{c}0.731^{* * *} \\
(0.247)\end{array}$ & $\begin{array}{l}0.772^{* *} \\
(0.329)\end{array}$ & $\begin{array}{c}0.732^{* * *} \\
(0.140)\end{array}$ & $\begin{array}{l}-0.015 \\
(0.020)\end{array}$ \\
\hline JV & $\begin{array}{c}1.468^{* * *} \\
(0.146)\end{array}$ & $\begin{array}{c}1.436^{* * *} \\
(0.156)\end{array}$ & $\begin{array}{c}1.351^{* * *} \\
(0.304)\end{array}$ & $\begin{array}{l}0.180^{*} \\
(0.106)\end{array}$ & $\begin{array}{c}0.112^{* * *} \\
(0.016)\end{array}$ \\
\hline Index PatCit*JV & & & $\begin{array}{c}1.275^{* * *} \\
(0.479)\end{array}$ & & \\
\hline Index PatClasses*JV & & & $\begin{array}{l}-0.220 \\
(0.522)\end{array}$ & & \\
\hline Observations & 11,468 & 11,468 & 11,468 & 11,468 & 3,035 \\
\hline 3digit-IPC-FE & $\mathrm{x}$ & & $\mathrm{x}$ & $\mathrm{x}$ & $\mathrm{x}$ \\
\hline Inventor-Region-FE & & $\mathrm{x}$ & & & \\
\hline Time-FE & $\mathrm{x}$ & $\mathrm{x}$ & $\mathrm{x}$ & $\mathrm{x}$ & $\mathrm{x}$ \\
\hline $\begin{array}{l}\text { Notes: Table shows point } \\
\text { the impact of public paten } \\
\text { regional forward citations ( } \\
\text { citations by firms (applican } \\
\text { regressions include a full set } \\
\text { for the number of backwarc } \\
\text { PatClasses for the number } \\
\text { dividing each variable by } \mathrm{t} \\
\text { stands for joint venture be } \\
*, * *, * * * \text { denote statistical } \mathrm{s} \\
\text { RegPAT and Citation data }\end{array}$ & $\begin{array}{l}\text { timates of } n \\
\text { characterist } \\
\text { l. (4)) and } \\
\text { weighted) n } \\
\text { f time dum } \\
\text { patent citat } \\
\text { f IPC class } \\
\text { e maximum } \\
\text { veen firms } \\
\text { vnificance at } \\
\text { ase, } 1995-20\end{array}$ & $\begin{array}{l}\text { egative binom } \\
\text { ics on the nu } \\
\text { he share of re } \\
\text { ithin } 5 \text { years } \\
\text { nies (based on } \\
\text { ons, Non-Pat } \\
\text { es. The index } \\
\text { value of the } \\
\text { nd public ins } \\
\text { the } 10,5 \text { and } \\
15 .\end{array}$ & $\begin{array}{l}\text { al model }(\mathrm{cc} \\
\text { iber of regic } \\
\text { ional forwar } \\
\text { ter the pub } \\
\text { he applicat } \\
\text { it for the nı } \\
\text { variables a } \\
\text { espective va } \\
\text { itutions. B } \\
1 \% \text { level. } S\end{array}$ & $\begin{array}{l}\text { (1) to (4)) and OLs } \\
\text { forward citations } \\
\text { itations (col. (5)). } \\
\text { tion of the public p } \\
\text { date of the public p } \\
\text { ber of backward non } \\
\text { the normalized vers } \\
\text { ble in the same IPC } \\
\text { strapped standard } \\
\text { ce: Authors' calcula }\end{array}$ & $\begin{array}{l}\text { model (col. (5)) for } \\
\text { col (1) to (3)), non- } \\
\text { itations include only } \\
\text { tent application. Al } \\
\text { tent). PatCit stands } \\
\text { patent citations and } \\
\text { ons of the variables } \\
\text { class and year. JV } \\
\text { rrors in parenthesis } \\
\text { ion based on OECD }\end{array}$ \\
\hline
\end{tabular}

as above, but instead of using the citations received we use the number of cited firm patents by a particular public patent as the dependent variable. The sample period shifts thus to 2000 to 2015 . The average public patent cites 0.02 regional patents and 0.54 non-regional patents. When taking all citations into account and ignoring the time dimension the average public patent cites 1.8 patents. The regression results (see Table 4) suggest that public patents with a wider scope do not cite more regional firm patents, which mitigates concerns about reverse causality. Moreover, we find that joint venture public patents are more likely to cite regional firm patents, which 
is in line with the notion that collaborations are mainly local. ${ }^{30}$

Table 4: Results for Number of Citations $B Y$ Public Patents

\begin{tabular}{|c|c|c|c|c|c|}
\hline \multirow[t]{2}{*}{$\begin{array}{l}\text { Model } \\
\text { Dep. Var. }\end{array}$} & & $\begin{array}{l}\text { Negat } \\
\text { \# Regiona } \\
\text { ited Pater }\end{array}$ & e Binomia & $\begin{array}{l}\text { Non-Regional } \\
\text { Cited Patents }\end{array}$ & \multirow{2}{*}{$\begin{array}{c}\text { OLS } \\
\begin{array}{c}\text { Share Regional } \\
\text { Cited Patents }\end{array} \\
(5)\end{array}$} \\
\hline & (1) & $(2)$ & (3) & (4) & \\
\hline Index PatClasses & $\begin{array}{l}-0.331 \\
(0.389)\end{array}$ & $\begin{array}{l}-0.315 \\
(0.416)\end{array}$ & $\begin{array}{l}-0.241 \\
(0.612)\end{array}$ & $\begin{array}{l}-0.054 \\
(0.099)\end{array}$ & $\begin{array}{l}-0.003 \\
(0.013)\end{array}$ \\
\hline JV & $\begin{array}{c}2.094^{* * *} \\
(0.158)\end{array}$ & $\begin{array}{c}1.928^{* * *} \\
(0.172)\end{array}$ & $\begin{array}{c}2.139 * * * \\
(0.253)\end{array}$ & $\begin{array}{c}0.251^{* * *} \\
(0.043)\end{array}$ & $\begin{array}{c}0.066^{* * *} \\
(0.008)\end{array}$ \\
\hline Index PatClasses*JV & & & $\begin{array}{l}-0.151 \\
(0.648)\end{array}$ & & \\
\hline Observations & 147,88 & 14,788 & 14,788 & 14,788 & 3,966 \\
\hline 3digit-IPC-FE & $\mathrm{x}$ & & $\mathrm{x}$ & $\mathrm{x}$ & $\mathrm{x}$ \\
\hline Inventor-Region-FE & & $\mathrm{x}$ & & & \\
\hline Time-FE & $\mathrm{x}$ & $\mathrm{x}$ & $\mathrm{x}$ & $\mathrm{x}$ & $\mathrm{x}$ \\
\hline
\end{tabular}

Notes: Table shows point estimates of negative binomial model (col. (1) to (4)) and OLS model (col. (4)) for the impact of public patent characteristics on the number of cited regional (col. (1) to (3)), cited nonregional (col. (4)) and the share of cited regional corporate patents (col. (5)). The number of cited patents includes only corporate patents (applicant-weighted) within 5 years after the publication of the corporate patent application. All regressions include a full set of time dummies (based on the application date of the public patent). PatClasses stands for the number of IPC classes. The index variable is the normalized version of this variable, dividing the variable by the maximum value of the variable in the same IPC Class and year. JV stands for joint venture between firms and public institutions. Bootstrapped standard errors in parenthesis. ${ }^{*}, * *, * * *$ denote statistical significance at the 10,5 and $1 \%$ level. Source: Authors' calculation based on OECD RegPAT and Citation database, 1995-2015.

\subsection{Transmission Channel Analysis}

We now turn to the transmission channel analysis in which we investigate the knowledge spillovers of public R\&D related to (i) a firm collaborating with a public institution (collaboration spillovers), (ii) a firm citing a public patent (technological spillovers) and (iii) a firm locating in a region in which public patents are produced (non-specific knowledge spillovers).

Methodology: To assess the impact of the three channels, we use a negative binomial model again. It reads as follows:

\footnotetext{
${ }^{30}$ While it would be of interest to assess the link explicitly, the patent data does not allow us to do so. Since inventors cannot be matched to applicants, the true firm R\&D location cannot be determined.
} 


$$
C P_{i, r, t}=f\left(c_{i, r}, J V_{i, r, t}, \text { Cited }_{i, r, t}, P P_{r, t}, X_{r, t}, \omega_{t}\right)+\epsilon_{i, r, t}
$$

The dependent variable is the number of corporate patents filed by firm (applicant) $i$ in region $r$ at time $t$ excluding joint venture patents with public institutions. The level of analysis is thus at the applicant-region level and includes the years 2000 to 2010 for all applicant-region combinations in which at least one corporate patent application has been filed between 1995 and 2015. ${ }^{31}$

Our three main explanatory variables capture the above mentioned transmission channels considered in our analysis. First, to capture collaboration spillovers we include an indicator variable that is one if applicant $i$ in region $r$ filed a patent with a public institution jointly $\left(J V_{i, r, t}\right)$ in year $t$. Second, to capture technological spillovers we include an indicator variable that is one if the applicant $i$ in region $r$ cited a public patent in a patent application in $t\left(\right.$ Cited $\left._{i, r, t}\right) .{ }^{32}$ Third, we use the number of public patents in region $r$ in year $t$ to capture non-specific knowledge spillovers $\left(P P_{r, t}\right)$ as this knowledge is likely to be linked to the number of innovations. ${ }^{33}$ Since we expect that the non-specific knowledge spillovers require firms to have close links with public institutes in order to access the non-specific knowledge, we interact the number of public patents in a region with an indicator variable that is one if applicant $i$ in region $r$ has collaborated with a public institution in the past or cited a public patent.

To assess the empirical support for the considered channels, we use a slightly different sample for each channel (but always account for all three channels). This

\footnotetext{
${ }^{31}$ We exclude applicant-region combinations in which less than one corporate patent application has been filed to increase the efficiency of the estimates.

${ }^{32}$ More precisely, we use the number of joint ventures as well as the number of citations of public patents. For most of the firms, however, only one collaboration or one citation is observed.

${ }^{33}$ One alternative indicator for the non-specific public knowledge suggested in the literature is the number of scientific publications (see, for example, Narin et al., 1997; Van Looy et al., 2006). While we observe scientific publications of research institutes and universities in the backward citations of patent application data, we refrain from using them in our analysis as this would induce a systematic measurement error (as only relevant publications are observed).
} 
is motivated by two reasons: First, when analyzing the citation channel for the dependent variable we do not use the overall number of corporate patents (applicant and inventor weighted) but only the corporate patents that do not cite public patents as otherwise there would be a mechanical link. Second, applicants that collaborate with public institutions or cite public patents might be very different from firms that do not (see, for example, the discussion in Scandura, 2016, for industryuniversity collaborations). Thus, by choosing a particular sample of firms we aim to address at least partly a potential selection. Our sample to assess the evidence for collaboration/joint venture (citing a public patent) spillovers includes only firms that collaborated with a public institution (cited a public patent) in at least one region between 1995 and 2015 (JV and CITED sample). To assess the evidence for non-specific knowledge spillovers we use the full sample. ${ }^{34}$ Moreover, to investigate the impact of public patent quality for the three channels, we include in additional specifications 1 less the quality indicator, based on the patent scope (number of IPC classes). The main advantage of this strategy is that it does not assume that we measure quality correctly.

Our set of control variables in all estimations includes applicant-region fixed effects $\left(c_{i, r}\right)$ as well as time-fixed effects $\left(\omega_{t}\right) .{ }^{35}$ Further, we control for a wide range of region characteristics $\left(X_{r, t}\right)$ following prior literature (e.g. Abramovsky et al., 2007; Abel and Deitz, 2011). These include measures for the local labor market (population, unemployment rate, share of high skilled and share of low skilled workers and number of students (per 1.000 inhabitants)) as well as measures for agglomeration (manufacturing employment) and urbanization (share of manufacturing employment). Moreover, we account for the tax burden on properties and business income

\footnotetext{
${ }^{34}$ Since the negative binomial model did not converge for the full sample, we report the estimates of a Poisson model with robust standard errors. For the negative binomial model, we report bootstrapped standard errors.

${ }^{35}$ The applicant-region fixed effects are included by estimating a conditional negative binomial model since the number of fixed effects is too large to include them in a negative binomial model. While the conditional negative binomial is not a real fixed effect model, the results are very similar when using a fixed effect Poisson model. Results are available upon request.
} 
in a region. ${ }^{36}$ Lastly, we account for the fact that during our sample period, Belgium, the Netherlands and Luxembourg have introduced patent boxes in 2006 and 2007. We define two indicator variables that are one if a county belongs to the $25 \%$ closest counties to Belgium or the Netherlands (or Luxembourg). The indicator variables are interacted with the respective reform dummies.

Descriptive statistics for the three samples are reported in Table A.1 in the Appendix. They suggest that applicants that collaborate with a public institution or cite a public patent are very similar and somewhat different from the average applicant. The average number of corporate patents in the JV and CITED sample is 0.51 but only 0.29 in the full sample. Further, the average county population of a collaborating as well as citing applicant is somewhat smaller than for the average applicant $(270,000$ vs. 300,000$)$. The same is true for the average number of public patents (4.6 vs 5.2). In the JV sample, the mean of the number of joint ventures is 0.02 (compared to 0.01 in the CITED sample).

Results: In the following we present the regression results. We start with the impact of joint venture public patents on the collaborating firm patenting behavior. To rule out that firms that collaborate with public institutions exhibit a different patent application pattern before the joint venture, we start by estimating a more flexible specification that includes 5 leads and 5 lags for the joint venture variable. The resulting point estimates highlight two aspects (see Figure 6). First, there is evidence that in the year of the joint application as well as the year before and after, the collaborating firm files more corporate patent applications in the region in which it collaborated. The anticipation effect is not surprising as the collaboration is likely to have started before the year of the joint application. Second, the effects for the years $t+5$ to $t+2$ are close to zero (with the exception of $t+3$ ). Thus, there is some evidence that collaborating firms have similar pre-trends compared to firms that collaborated with public institutions at a different point in time. However, the reader should note that this does not imply that our estimates represent causal effects

\footnotetext{
${ }^{36}$ Since the tax rates are municipality-specific, we construct the county-averages using the municipalities' population in 1999.
} 
Figure 6: Estimates for JV - Not Quality Adj. and All Firms

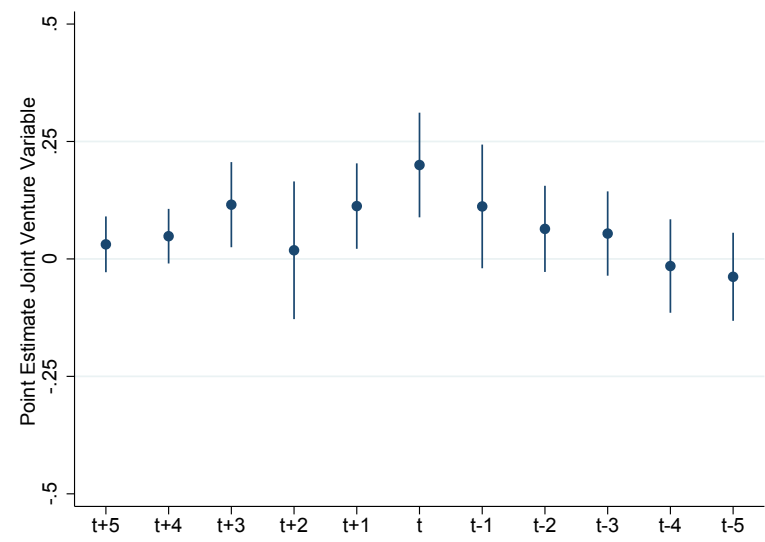

Notes: Figure shows point estimates for 5 leads and 5 lags of the joint venture (JV) variable. The dependent variable is the number of corporate patent applications (applicant and region-weighted) excluding patent applications that are filed jointly with a public institution. The specification uses the same sample and includes the same control variables as the specification shown in col. (1) in Table 5. More precisely, the sample includes all firms and the joint venture variable is not quality adjusted. Source: Authors' calculations based on INKAR and OECD RegPat database, 2000 to 2010.

as they could still be biased due to, for example, a self-selection of firms.

To assess the role of public patent quality, heterogeneity of the impact as well as possible spillovers to other regions, we rely on a regression analysis in the following and focus only on the same-year impact of joint ventures (acknowledging that this is likely to underestimate the overall impact of this particular channel). Col. (1) in Table 5 shows the results of our baseline specification, which replicates the results reported in Figure 6: Collaborating with a public institution coincides with an increase in the number of corporate patent applications. The magnitude of the impact (around 20\%) is very similar to the results by Scandura (2016), who reports an increase in R\&D expenditure per employee of $17 \%$ for firms that collaborate with a university (at the end of the collaboration). In col. (2), we account for the quality of the joint venture public patents, measured by their scope. In line with the results of the citation analysis, the point estimate for $\mathrm{JV} *$ (1-Quality Index) is negative and statistically significant. Thus, higher quality joint venture public patents have a higher value to the collaborating firm. In col. (3) we only use low R\&D intensity 
firms (firms with less than 5 patent applications between 1995 and 1999) and in col. (4) only high R\&D intensity firms. The results suggest that the absolute increase in the number of patent applications for one additional joint venture public patent with a quality index of one is very similar for low and high R\&D intensity firms (0.39 vs 0.35 , see bottom of the Table). ${ }^{37}$ Col. (5) and (6) show that joint ventures have a larger impact on the absolute number of low quality firm patents, measured by their scope ( 0.30 vs. 0.17 , see bottom of the Table). A further insight relates to the extent of joint venture spillovers to other regions. We capture them by including the applicant-year specific number of joint ventures in all other regions. While our baseline specification suggests significantly positive spillovers to other regions, substantial heterogeneity seems to exist as in all other specifications the spillover effects are not statistically different from zero.

We turn to the results for the impact of citing a public patent on the citing firms' number of patent applications. As for joint ventures, we start presenting the results of the more flexible specification that includes 5 leads and 5 lags of the CITED variable (see Figure 7). The results suggest that firms that cite a public patent in a particular year file at the same time more patent applications (that do not cite a public patent). As for joint ventures, there is some evidence for positive effects in the year before and after. The point estimate for $\mathrm{t}+4$ to $\mathrm{t}+2$ are, however, very similar (although somewhat larger than zero), which suggests that the patenting behavior of firms before they cite a public patent is comparable to firms that cite public patents at a different point in time. However, as before this does not necessarily imply causality as self-selection could still bias our estimates.

The regression results for the (current year) impact of citing a public patent are reported in Table 6 . The baseline specification (col. (1)) replicates the finding reported in Figure 7. The point estimate is only smaller which is in line with the somewhat larger number of patent applications before the citation. Accounting for quality differences matters (see col. (2)), the interaction effect is negative and statis-

\footnotetext{
${ }^{37}$ The absolute increase is calculated by multiplying the point estimate with the mean of the dependent variable, shown in the bottom of the table.
} 
Table 5: Results for Impact of JV of Firms with Public Institutions

\begin{tabular}{lcccccc}
\hline $\begin{array}{l}\text { Model } \\
\text { Dep. Var. }\end{array}$ & \multicolumn{7}{c}{ Negative Binomial } \\
$\begin{array}{l}\text { Firms } \\
\text { Patent Quality }\end{array}$ & All & All & Low R\&D & High R\&D & All & All \\
& All & All & All & All & High & Low \\
\hline \# JV & $(1)$ & $(2)$ & $(3)$ & $(4)$ & $(5)$ & $(6)$ \\
\hline [JV*(1-QI)] & $0.204^{* * *}$ & $0.465^{* * *}$ & $0.774^{* * *}$ & $0.288^{* *}$ & $0.638^{*}$ & $0.478^{* * *}$ \\
& $(0.043)$ & $(0.123)$ & $(0.281)$ & $(0.145)$ & $(0.341)$ & $(0.156)$ \\
\# JV OR & & $-0.383^{* *}$ & -0.598 & -0.224 & -0.526 & $-0.421^{*}$ \\
& & $(0.182)$ & $(0.425)$ & $(0.210)$ & $(0.494)$ & $(0.233)$ \\
\# [JV OR*(1-QI)] & $0.004^{* * *}$ & -0.011 & -0.126 & -0.018 & 0.128 & 0.025 \\
& $(0.001)$ & $(0.011)$ & $(0.115)$ & $(0.016)$ & $(0.315)$ & $(0.046)$ \\
& & 0.022 & 0.161 & 0.032 & -0.136 & -0.029 \\
Observations & 73,395 & 73,395 & 20,685 & 52,710 & 73,395 & 73,045 \\
Applicant-Region-FE & $\mathrm{x}$ & $\mathrm{x}$ & $\mathrm{x}$ & $\mathrm{x}$ & $\mathrm{x}$ & $\mathrm{x}$ \\
Time-FE & $\mathrm{x}$ & $\mathrm{x}$ & $\mathrm{x}$ & $\mathrm{x}$ & $\mathrm{x}$ & $\mathrm{x}$ \\
Control Variables & $\mathrm{x}$ & $\mathrm{x}$ & $\mathrm{x}$ & $\mathrm{x}$ & $\mathrm{x}$ & $\mathrm{x}$ \\
Dep. Var CP & 0.89 & 0.89 & 0.51 & 1.23 & 0.28 & 0.62 \\
CP OR & 29.92 & 29.92 & 2.91 & 54.20 & 8.45 & 21.59
\end{tabular}

Absolute increase in the number of corporate patents if JV increases by one with average QI $\quad 0.18$
with $\mathrm{QI}=1$
0.42
0.39
0.35
0.17
0.30

Notes: Table shows point estimates of negative binomial model for the impact of collaborating with a public institution (measured by filing a joint public patent application) on the number of corporate patent applications (applicant and region-weighted) excluding patent applications that are filed jointly with a public institution. JV stands for joint venture, QI for quality index and OR for other regions. All regressions include time and applicant-region fixed effects as well as the control variables described in the text. Col. (1) shows the baseline specification. Col. (2) accounts for the quality of the jointly filed public patent. Col. (3) uses only low R\&D intensity firms (less than 5 patent applications between 1995 and 1999) and col. (4) only high R\&D intensity firms. In col. (5) the dependent variable is the number of high quality corporate patents (sum over corporate patents multiplied with the quality index) and in col. (6) the number of low quality corporate patents (sum over corporate patents multiplied with 1 less quality index). The quality index is based on the number of patent classes a patent is filed for. For more information see the text. The absolute increase in the number of corporate patents if JV increases by one is calculated by multiplying the JV coefficient with the mean of the dependent variable (shown in the bottom of the Table as well). Bootstrapped standard errors in parenthesis. $*, * *, * * *$ denote significance at the 10,5 and $1 \%$ level. Source: Authors' calculation based on INKAR and OECD RegPAT 2000-2010.

tically significant. Col. (3) and (4) show that the absolute increase in the number of corporate patents for citing one additional public patent is somewhat larger for high R\&D intensity firms (1.1 vs. 0.7, see bottom of the Table). Moreover, the results in col. (5) and (6) suggest that the absolute impact is larger for low quality patents (0.53 vs. 0.28$)$. With respect to spillovers into other regions, we find evidence for 
Figure 7: Estimates for CITED - Not Quality Adj. and All Firms

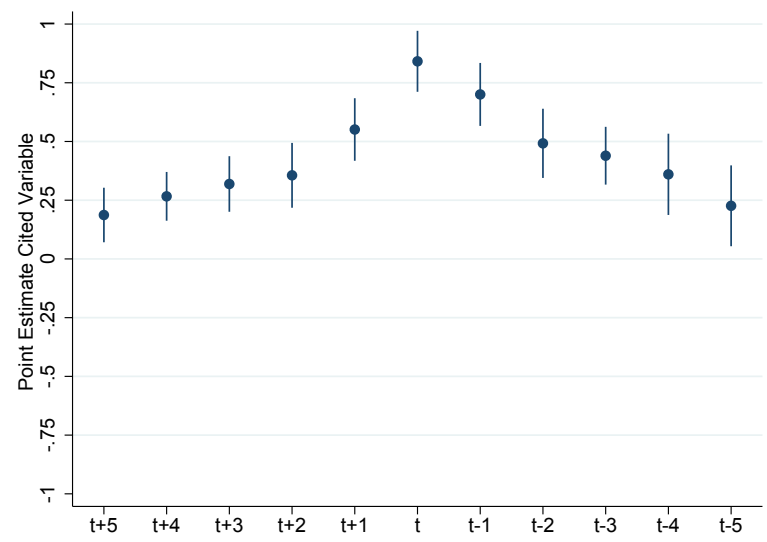

Notes: Figure shows point estimates for 5 leads and 5 lags of the CITED variable. The dependent variable is the number of corporate patent applications (applicant and region-weighted) excluding patent applications that cite a public patent. The specification uses the same sample and includes the same control variables as in col. (1) in Table 6. More precisely, the sample includes all firms and the CITED variable is not quality adjusted. Source: Authors' calculations based on INKAR, OECD RegPat and Citation database, 2000 to 2010.

positive ones (col. (1) and col. (2)). Surprising is, however, that the spillovers into other regions are significantly larger for low R\&D intensity firms if the cited public patent has a lower quality (based on its patent scope, see col. (3)). Thus, the spillovers within the firm from citing a low quality public patent are less localized compared to the spillovers within the firm from citing a high quality public patent. One potential adhoc explanation for this finding is that public R\&D producers not only produce public knowledge but also provide important inputs for the firm $R \& D$ that is stimulated by high quality public R\&D, potentially due to the provision of research infrastructure or due to their non-specific knowledge.

Lastly, we explore whether there are non-specific knowledge spillovers of public R\&D. As before, we focus on the current year impact. ${ }^{38}$ The result, reported in Table 7, suggests so (additional to the collaboration and technological spillovers for which we control), assuming that the number of public patents is a reasonable proxy

\footnotetext{
${ }^{38}$ Unfortunately, estimating the more flexible specification is not possible as the model no longer converges.
} 
Table 6: Results for Impact of Citing a Public Patent

\begin{tabular}{|c|c|c|c|c|c|c|}
\hline $\begin{array}{l}\text { Model } \\
\text { Dep. Var. } \\
\text { Firms } \\
\text { Patent Quality }\end{array}$ & $\begin{array}{l}\text { All } \\
\text { All }\end{array}$ & $\begin{array}{l}\text { All } \\
\text { All }\end{array}$ & $\begin{array}{l}\text { Negative } \\
\text { \# Corporate } \\
\text { Low R\&D } \\
\text { All }\end{array}$ & $\begin{array}{l}\text { Binomial } \\
\text { Patents (CP) } \\
\text { High R\&D } \\
\text { All }\end{array}$ & $\begin{array}{c}\text { All } \\
\text { High }\end{array}$ & $\begin{array}{l}\text { All } \\
\text { Low }\end{array}$ \\
\hline Patent Quality & (1) & $(2)$ & (3) & (4) & (5) & (6) \\
\hline \# Cited & $\begin{array}{c}0.639^{* * *} \\
(0.040)\end{array}$ & $\begin{array}{c}0.909^{* * *} \\
(0.141)\end{array}$ & $\begin{array}{c}1.135^{* * *} \\
(0.204)\end{array}$ & $\begin{array}{c}0.730^{* * *} \\
(0.219)\end{array}$ & $\begin{array}{c}0.925^{* * *} \\
(0.175)\end{array}$ & $\begin{array}{c}0.741^{* * *} \\
(0.121)\end{array}$ \\
\hline \# [Cited*(1-QI)] & & $\begin{array}{c}-0.408^{* *} \\
(0.192)\end{array}$ & $\begin{array}{c}-0.859^{* * *} \\
(0.292)\end{array}$ & $\begin{array}{l}-0.290 \\
(0.289)\end{array}$ & $\begin{array}{c}-0.489^{*} \\
(0.250)\end{array}$ & $\begin{array}{l}-0.215 \\
(0.164)\end{array}$ \\
\hline \# Cited OR & $\begin{array}{c}0.033^{* * *} \\
(0.004)\end{array}$ & $\begin{array}{c}0.030^{* *} \\
(0.014)\end{array}$ & $\begin{array}{c}0.008 \\
(0.051)\end{array}$ & $\begin{array}{c}0.019 \\
(0.014)\end{array}$ & $\begin{array}{c}0.041^{* * *} \\
(0.013)\end{array}$ & $\begin{array}{c}0.011 \\
(0.017)\end{array}$ \\
\hline \# [Cited OR*(1-QI)] & & $\begin{array}{c}0.003 \\
(0.024)\end{array}$ & $\begin{array}{c}0.164^{* *} \\
(0.075)\end{array}$ & $\begin{array}{c}0.030 \\
(0.022)\end{array}$ & $\begin{array}{c}-0.018 \\
(0.021)\end{array}$ & $\begin{array}{c}0.021 \\
(0.027)\end{array}$ \\
\hline Observations & 89,251 & 89,251 & 28,918 & 60,333 & 89,251 & 88,999 \\
\hline Applicant-Region-FE & $\mathrm{x}$ & $\mathrm{x}$ & $\mathrm{x}$ & $\mathrm{x}$ & $\mathrm{x}$ & $\mathrm{x}$ \\
\hline Time-FE & $\mathrm{x}$ & $\mathrm{x}$ & $\mathrm{x}$ & $\mathrm{x}$ & $\mathrm{x}$ & $\mathrm{x}$ \\
\hline Control Variables & $\mathrm{x}$ & $\mathrm{x}$ & $\mathrm{x}$ & $\mathrm{x}$ & $\mathrm{x}$ & $\mathrm{x}$ \\
\hline Dep. Var. CP & 1.026 & 1.026 & 0.631 & 1.527 & 0.299 & 0.727 \\
\hline CP OR & 22.747 & 22.747 & 3.726 & 46.852 & 6.196 & 16.564 \\
\hline \multicolumn{7}{|c|}{$\begin{array}{l}\text { Absolute increase in the number of corporate patents if Cited increases by one } \\
\text { with average QI } \\
0.66\end{array}$} \\
\hline $\begin{array}{l}\text { Notes: Table shows point } \\
\text { plication (within } 5 \text { years a } \\
\text { region-weighted) excluding } \\
\text { QI stands for quality index } \\
\text { effects as well as the contro } \\
\text { accounts for the quality of } \\
\text { than } 5 \text { patent application } \\
\text { dependent variable is the } n \\
\text { the quality index) and in co } \\
\text { tiplied with } 1 \text { less quality in } \\
\text { For more information see t } \\
\text { by one is calculated by mul } \\
\text { bottom of the Table as wel } \\
10,5 \text { and } 1 \% \text { level. Sourc } \\
2000-2010 \text {. }\end{array}$ & $\begin{array}{l}\text { and OR for } \\
\text { variables des } \\
\text { he public pat } \\
\text { etween } 1995 \\
\text { mber of high } \\
\text { (6) the num } \\
\text { lex). The qua } \\
\text { e text. The a } \\
\text { iplying the C } \\
\text { : Bootstrapp } \\
\text { Authors' c}\end{array}$ & $\begin{array}{l}\text { er regions } \\
\text { ibed in th } \\
\text { ts in a reg } \\
\text { d 1999) an } \\
\text { lality corp } \\
\text { ar of low q } \\
\text { y index is } \\
\text { olute incre } \\
\text { d coefficie } \\
\text { I standard }\end{array}$ & $\begin{array}{l}\text { All regressio } \\
\text { ext. Col. (1) } \\
\text {. Col. (3) ir } \\
\text { col. (4) only } \\
\text { te patents (s } \\
\text { ity corporate } \\
\text { sed on the nu } \\
\text { e in the num } \\
\text { with the mea } \\
\text { rors in paren }\end{array}$ & $\begin{array}{l}\text { he impact of } \\
\text { rate patent al } \\
\text { C Cited stands } \\
\text { include time } \\
\text { hows the basel } \\
\text { udes only low } \\
\text { gh R\&D inten } \\
\text { n over corpora } \\
\text { atents (sum or } \\
\text { ber of patent } \\
\text { of corporate } \\
\text { of the depend } \\
\text { lesis. *,**,*** } \\
\text { OECD RegPA }\end{array}$ & $\begin{array}{l}\text { iting a pub } \\
\text { plications } \\
\text { for citing a } \\
\text { and applicar } \\
\text { ine specifica } \\
\text { R\&D intens } \\
\text { sity firms. } \\
\text { te patents n } \\
\text { er corporat } \\
\text { lasses a pat } \\
\text { patents if } \\
\text { ent variable } \\
\text { denote sign }\end{array}$ & $\begin{array}{l}\text { patent ap- } \\
\text { licant and } \\
\text { lic patent, } \\
\text { egion fixed } \\
\text { l. Col. (2) } \\
\text { firms (less } \\
\text { ol. (5) the } \\
\text { iplied with } \\
\text { tents mul- } \\
\text { is filed for. } \\
\text { d increases } \\
\text { own in the } \\
\text { nce at the } \\
\text { database, }\end{array}$ \\
\hline
\end{tabular}

for them and that the additional firm patents are indeed caused by the additional public knowledge. While the effect is stronger for firms with close links to public institutions (CL), all other firms respond as well (1-CL). Accounting for quality does not seem to matter (col. (2)). The reason is, however, that there is a strong difference between the impact on low (col. (3)) and high R\&D intensity firms (col. (4)). While 
the first respond strongly, the latter do not seem to respond at all. Col. (5) and (6), which distinguish between high and low quality patents, also do not show meaningful results, which is again likely to be related to the striking difference between low and high R\&D intensity firms. We thus estimate the specifications in col. (5) and (6) for low and high R\&D intensity firms separately (not reported). The results suggest that both, the number of low and high quality patents by low R\&D intensity firms, increases.

Finally, while there is no evidence for spillovers into other regions on average, there is evidence - similar to the citation channel - for positive spillovers into other regions for low $R \& D$ intensity firms (that have close links to public institutions) in the case of low quality public R\&D. ${ }^{39}$ As mentioned above, one potential reason for this finding could be that public R\&D producers provide important inputs for the production of firm $R \& D$ that is stimulated by high quality public R\&D.

Discussion: In the following, we compare the results for the different channels and quantify their relative importance. This exercise is based on the assumption that all three channels are correctly measured and that the estimated effects are causal. We find that all three channels have a stronger effect on firm R\&D the higher the quality of public R\&D and that all three channels have a larger impact on the absolute number of low quality corporate patents. The main difference between the channels is the type of firms affected. While the citation and collaboration channel seem to affect low and high R\&D intensity firms largely to a similar extent, non-specific knowledge spillovers affect predominantly low R\&D intensity firms.

Based on our empirical strategy and the proxies employed, the non-specific local knowledge spillovers seem most important in quantitative terms. While the average effect is small (semi-elasticity of 0.012 for firms with close links to public institutions and 0.003 for firms with no close links, see col. (1) in Table 7), the number of firms affected in the average region with non-zero public patents is large; on average there are 8 firms with close links and 170 other firms. Thus, the average public

\footnotetext{
${ }^{39}$ Since there is not independent variation in the data, we are not able to assess the spillovers into other regions for firms with no close links to public institutions.
} 
patent generates via non-specific knowledge spillovers 0.08 additional public patents by firms with close links (absolute increase by 0.01 for 8 firms, see col (1) of Table 7) and 0.17 additional patents by firms with no links to public institutions (absolute increase by 0.001 for 170 firms, see col. (1) of Table 7). The collaboration as well as the citing channel are suggested to be less important. The number of additional local corporate patents generated via the citation link amounts to 0.03 (calculated by multiplying the absolute increase of 0.66 per additional public patent, see col. (1) in Table 6, with the number of regional applicants that cite a public patent on average, which is 0.046). The number of additional local corporate patents generated via the collaboration channel amounts to 0.04 (calculated by multiplying the absolute increase of 0.18 , see col. (1) of Table 5 , the share of joint venture public patents, 0.15 - assuming that all collaborations are local, and the number of collaborating firms per joint venture, which is 1.3). Adding all (one year) effects up suggests that one additional average public patent in a region generates 0.32 local firm patents (at different points in time). This implies - based on the assumption outlined above that the non-specific knowledge channel accounts for around $3 / 4$ of the overall effect. Since Walsh et al. (2016) show that only around $1 / 3$ of all collaborations lead to joint patent applications, $3 / 4$ should be considered as an upper bound. A lower bound may be derived by assuming that the collaboration channel is three times as important, while keeping the overall effect constant. In this case, the non-specific knowledge spillovers would account for around $1 / 2$ of the overall effect.

\section{Overall Magnitude of Local Public R\&D Spillovers}

Methodology: In the second part of the empirical analysis, we aim to quantify the overall magnitude of local knowledge spillovers and whether they are - as suggested by the transmission channel analysis - dominantly driven by low R\&D intensity firms. The analysis is at the county level and we employ an instrumental variable strategy since the OLS estimate may be biased due to measurement error (as the number of public patents is only an imperfect proxy for public knowledge 
production), reverse causality (as the funding of public R\&D may depend on firm $\mathrm{R} \& \mathrm{D}$ in a region) as well as omitted variables (e.g. the emergence of new technologies or direct subsidies).

While the direction of the overall bias cannot be determined a priori with certainty given the different reasons, we believe that the OLS estimate is most likely downward biased. This is based on the rationale that the measurement error, which arguably causes a downward bias, is likely to be severe due to our focus on patents and unobserved patent quality but also as we exploit changes over time. Reverse causality and omitted variable bias, in contrast, are likely to be less important given that we exploit variation over time and as the institutional funding for a particular institute is in Germany not only determined by the hosting state but by all states and the federal state. ${ }^{40}$ Furthermore, direct subsidies, which are a strong candidate for an omitted variable bias, are relatively less important in Germany. While the federal and the state governments fund 19 billion EURO R\&D expenditures in the government and higher education sector, they fund only 2 billion EURO R\&D expenditures in the business sector (out of 47 billion EURO). ${ }^{41}$

Based on these considerations, we choose the 4-year lagged institutional funding for Fraunhofer and Leibniz institutes that engage in R\&D activities as the excluded instrument. ${ }^{42}$ This instrument is very likely to address successfully the bias resulting

\footnotetext{
${ }^{40} \mathrm{In}$ more detail, the argument is as follows: We believe that the funding shares of hosting and non-hosting states (as well as the federal state) reflect the (average) expected magnitude of local and technological spillovers. While the funding share of the hosting state increases with the expected local spillovers (as the hosting-state only benefits from them), it decreases in the latter (as all states benefit from this dimension). Assuming rational behavior of state governments predicts than that a state's (marginal) willingness to fund a research institute equals the (marginal) benefits of funding. This means that non-hosting states (as well as the federal state's) willingness to fund a particular research institute depends largely on the expected magnitude of the technological spillovers. Since there are 16 states and most institutes operate in only one state, for 15 (out of 16) states the decision about the level of funding of a particular research institute is independent of the expected magnitude of local spillovers.

${ }^{41}$ German Federal Ministry of Finance, Data portal, Table 1.1.1 (http://www.datenportal . bmbf.de/portal/de/K11.html, last accessed 16/04/2020).

${ }^{42}$ The data for Leibniz institutes have been obtained from annual publications of the Leibniz Society. The data for Fraunhofer institutes have been provided by the Fraunhofer Society. We also collected information for Helmholtz institutes and have been provided with data for Max Planck
} 
from measurement error as the institutional funding is a second measure of public $\mathrm{R} \& \mathrm{D}$ production and unlikely to correlate with the measurement error in the number of public patents. Moreover, we believe our excluded instrument to at least partly mitigate the bias that results from reverse causality and omitted variables. First, we focus on institutional funding instead of overall $R \& D$ expenditures to rule out an obvious reverse causality, which may exist as research institutes do carry out R\&D on behalf of firms. Second, we use the 4-year lagged institutional funding since a time lag between the institutional funding decision and the number of firm patent applications reduces a potential correlation of institutional funding with the number of firm patent applications in a region, either directly or via omitted variables (e.g. the emergence of a new technology or direct subsidies). ${ }^{43}$ While a longer period would certainly be better, our choice of the 4-year lagged institutional funding ensures that the instrument is still sufficiently strong. Moreover, the reader should note that in all specifications region fixed effects are included to absorb a large part of potentially omitted variables and to account for the persistence in public as well as private $R \& D$. To avoid that institute openings or closures affect our instrument, we construct it only for institutes that existed over our sample period.

Our estimation model reads as follows:

$$
\ln C P_{r, t}=c_{r}+\beta_{1} P P_{r, t}+\beta_{2} P P_{r, t}^{2}+\gamma X_{r, t}+t_{t} \epsilon_{r, t}
$$

We use a log-linear model as it allows a straight forward implementation of the instrumental variable strategy and correct standard errors can easily be obtained. Moreover, count models with a large number of county-fixed effects tend to be some-

institutes by the Max Planck Society. For Max Planck institutes the data only starts in 2005 and for the Helmholtz institutes the data is less precise as Helmholtz institutes usually consist of several establishments and we were only able to collect institutional funding data on the institute level.

${ }^{43}$ Direct subsidies provide a good illustration of this argument. While we find a positive and statistically significant correlation of the growth rate of overall direct subsidies and the growth rate of overall public funding for research institute in the aggregate (correlation coefficient: $0.76, \mathrm{p}$-value: 0.03), no correlation exists between the growth rate of direct subsidies and the 4-year lagged growth rate of overall public funding for research institutes (correlation coefficient: -0.09 , p-value: 0.82). 
what fragile. ${ }^{44}$ We report robust standard errors. Our sample period is - due to the availability of the excluded instrument - 2003 to 2010, which leaves us with 3,212 county-year observations for 402 counties (since for 4 observations the number of firm patents is zero).

Figure 8: Reasons for a Potential Non-Linear Impact of Public on Firm R\&D

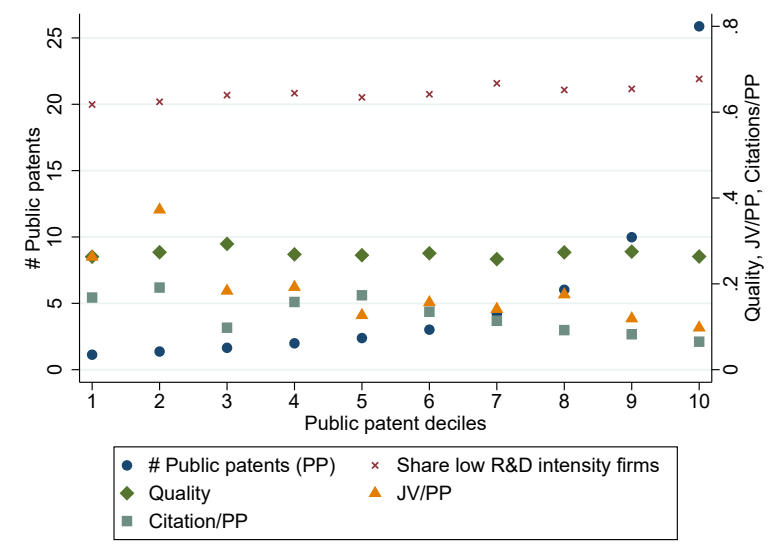

Notes: Figure shows average number of public patents, average quality of public patents, share of low R\&D intensity firms, number of joint venture applicants per public patent and number of citing applicants per public patent within a region for public patent deciles (at least one public patent). Source: Authors' calculation based on OECD RegPat and Citation database, 2003-2010.

Our dependent variable is (ln) number of corporate patents in region $r$ at time $t$ (both applicant and inventor weighted and including joint venture patents with public institutions). Our main explanatory variable of interest is the number of public patents in region $r$ at time $t$. We use the quality unadjusted number of public patents as our instrument is unfortunately not strong enough to predict the quality adjusted number of public patents. To account for a potential nonlinear relationship we include the number of public patents linear and squared. The relationship could be nonlinear for a variety of reasons. First, there is evidence that the number of low

\footnotetext{
${ }^{44}$ We assessed the robustness of our estimation strategy by estimating a fixed effect Poisson model coupled with a control function approach in addition. Results are very similar and available upon request.
} 
R\&D intensity firms is increasing with the number of public patents in a region (see Figure 8). Moreover, the number of firms that collaborate with public institutions in a region per public patent as well as the number of firms in a region that cite a public patent per public patent are decreasing with the number of public patents. The only dimension that does not seem to matter is the average quality of public patents.

Our set of control variables $\left(X_{r, t}\right)$ is the same as for the transmission channel level analysis but with county $\left(c_{r}\right)$ instead of applicant-region fixed effects. Descriptive statistics for our sample, reported in Table 8, show that the average county has 200.000 inhabitants, around 64 corporate patents and 2 public patents, $30 \%$ of them are from universities and $70 \%$ from research institutes.

Results: The regression results are reported in Table 9. Col. (1) reports the OLS estimate and col. (2) the IV estimate when including only the number of public patents. While the OLS point estimate is statistically significant, it is close to zero and would suggest an increase in the number of corporate patents by 0.3 for one additional public patent, which matches the result of the transmission channel analysis. The IV point estimate is substantially larger, but is not precisely estimated, despite the fact that the instrument is relevant, as suggested by the test-statistics, and has the expected sign (see bottom of the Table). From col. (3) onward we include the number of public patents squared in addition. While in both, the uninstrumented (col. (3)) and instrumented specification (col. (4)), the squared number of public patents is negative and thus suggests a nonlinear relationship, only the IV point estimates are (marginally) significant. To test whether the impact of public on firm patents is indeed nonlinear, we employ the modified Ramsey's regression error specification test (RESET) by Hashem Pesaran and Taylor (1999), which tests for neglected non-linearities. The p-value of the test using 2 nd and 3 rd order polynomials are reported in the bottom of the Table. While there are neglected non-linearities in the specification using only public patents (p-value below 10\%, col. (2)), this is not the case when using public patents linear and squared. Moreover, we assess whether the number of public patents squared simply picks up region-size heterogeneity as there are more public patents in larger regions. Col. (5) shows the results 
when additionally including the interaction of the number of public patents with the population in 2002 (in million). While the size of a region seems to matter, more populated areas benefit more and not less from public R\&D. Further, the point estimate for the squared number of public patents is largely unchanged. Thus, we conclude that the effect of public $R \& D$ is nonlinear and increases at a decreasing rate in the level of public patents. ${ }^{45}$

To assess the sensitivity of the results, we run several robustness checks (see Table A.2 in the Appendix). First, we include state-year-fixed effects (col. (1)). Second, we use $(\mathrm{ln})$ number of $\mathrm{R} \& \mathrm{D}$ employees in a region as an alternative proxy for firm $\mathrm{R} \& \mathrm{D}$ (col. (2)). While the number of firm R\&D employees is only available for 2003, 2005, 2007 and 2009, it is based on a full-assessment of firms' R\&D activities in Germany. In both specifications point estimates are unchanged, only the precision is reduced. Our third robustness test excludes regions with an average number of corporate patents in the top $1 \%$ of the distribution (col. (3)) to assess whether outliers are driving the results. The estimates are very similar and even more precisely estimated (significant at the 5\% level), likely due to a higher instrument relevance. Lastly, we address whether agglomeration economies bias our results and include the number of corporate patent applications filed in a region between 1991 and 2000 interacted with year dummies (col. (4)). The results are basically unchanged.

Next we investigate which firms and which corporate patents respond to public $\mathrm{R} \& \mathrm{D}$ in a region (see Table 10). In col. (1) to (3) we use the number of corporate patent applications filed by low R\&D intensity firms and in col. (4) to (6) by high R\&D intensity firms as dependent variable. Col. (1) and (4) show the baseline specification, in col. (2) and (5) we use only high quality corporate patents and in col. (3) and (6) only low quality corporate patents (based on their scope). The result suggests that it is in particular low R\&D intensity firms that respond to local public

\footnotetext{
${ }^{45}$ More precisely, the effect increases at a decreasing rate in the level of public patents for $99 \%$ of the jurisdictions in our sample. For the remaining 1\% (which account for around $20 \%$ of the overall number of public patents in Germany) the marginal effect is suggested to be negative. Since the latter group is small and the finding could, therefore, result from a misspecified functional form, it should be interpreted with caution.
} 
R\&D (col. (1) vs. col. (4)), the point estimates are larger in absolute terms and also more precisely estimated. ${ }^{46}$ Moreover, the point estimates are similar for high quality (col. (2)) and low quality patents (col. (3)) of low R\&D intensity firms. The absolute impact is, however, larger for low quality patents since low R\&D intensity firms produce more low quality patents (see bottom of the table). Thus, our results are in line with the findings of the transmission channels.

Lastly, we investigate whether previously non-patenting firms start patenting, which could indicate university-spin offs, or whether previously patenting low R\&D intensity firms patent more (see col. (5) and (6) of Table A.2 in the Appendix). The result suggests that both low $R \& D$ intensity type firms respond to public patents but previously non-patenting firms are relatively less important as previously patenting firms have a 2.5 times higher average number of firm patent applications (col. (6)).

Discussion: While the IV results are qualitatively in line with the results of the transmission channel analysis, the effect size is substantially larger. This is consistent with a more severe measurement error (and/or a counter-cyclical reverse causality bias) and a less severe omitted variable bias, assuming that the latter would cause an upward bias. The IV estimates could, however, still be biased by reverse causality and omitted variables as the 4-year lag may be too short.

Based on the assumption of unbiased IV estimates, our results imply a semielasticity of 0.1 in the median county with non-zero public patents and thus that one additional public patent creates 3.2 additional corporate patents (based on the median number of firms in our sample). ${ }^{47}$ Given that our transmission channel analysis does not suggest negative spillover effects into other regions by firms that benefit from public R\&D within a region, 3.2 additional public patents within a region is a substantial effect. Whether this means that public $R \& D$ is an effective way to stimulate local public R\&D depends, however, also on the cost of producing the (marginal) public patent. Since we only have institutional funding data for

\footnotetext{
${ }^{46}$ The fact that the point estimates have the opposite sign for high R\&D intensity firms is unlikely to suggest that the additional patents of low $R \& D$ intensity firms come at the costs of high $R \& D$ intensity firms as the overall effect is positive.

${ }^{47}$ We focus on the median as the distribution of patent applications is skewed.
} 
Fraunhofer and Leibniz institutes, we assume costs per public EPO patent of 4.5 million EURO based on the estimate by Dechezlepretre et al. (2016) for UK firms. ${ }^{48}$ This implies that one additional corporate patent costs 1.4 million EURO using public knowledge production as firm R\&D support strategy. To put these costs into perspective, we compare them to the public costs per firm patent application using another widely employed firm R\&D support strategy, namely R\&D tax credits. Two recent papers, one for the US and for the UK, estimate a ratio of value to money of 1.7 for R\&D tax credits (see Rao, 2016; Dechezlepretre et al., 2016). Thus, if we assume that a corporate patent by a German firm costs 4.5 million EURO, 2.6 million EURO in R\&D tax credits need to be spent. It thus seems less expensive to stimulate firm $R \& D$ by creating knowledge outside the firm than by providing financial incentives to the firm.

An additional insight of the IV analysis is that the impact of public R\&D on local firm R\&D is decreasing in the level of public patents. Since our analysis shows that in particular low R\&D intensity firms benefit from public R\&D, the nonlinear relationship is unlikely to result from an uneven distribution of low R\&D intensity firms. One explanation brought forward in the literature to explain a crowding out of private $R \& D$ by public $R \& D$ is the $R \& D$ employee wage channel: More public patents increase the costs for $R \& D$ employees in a region and thereby decrease $R \& D$ by firms. Since we do, however, not find evidence that high R\&D intensity firms file less patent applications in response to public patents, this suggests that two R\&D employee labor markets exist, one for low R\&D intensity firms (and public institutions) and one for high R\&D intensity firms. This would also explain why high R\&D intensity firms do not benefit from local public R\&D. The point estimates for our control variables (see Table A.3) are in line with this presumption. While the share of skilled labor has a negative impact (also not statistically significant) on the number of corporate patents for low R\&D intensity firms, the impact is positive

\footnotetext{
${ }^{48}$ This estimate seems reasonable compared to the average expenditures of research institutes per public patent in Germany (excluding own income and expenditures for research in humanities, see Table 1), which is 5.3 million EURO.
} 
(although again not statistically significant) for high R\&D intensity firms.

\section{Conclusion}

In this paper, we aim to shed light on the overall magnitude of local knowledge spillovers of public R\&D by universities and research institutes on firm $R \& D$ in Germany as well as its determinants. We proxy R\&D activities by the number of patent applications observed in the OECD RegPat database. We find evidence that is consistent with the existence of three distinct transmission channels on the local level. First, firms that collaborate with a (local) public institution file more patent applications at the time of the collaboration. Second, firms that cite public patents also experience an increase in the number of patent applications around the time of citing the public patent. Third, firms that locate in a region in which public patents are produced file also more patent applications. While the results of our estimation strategy and the proxies employed suggest that the first and second channel have a substantial impact on the affected firm, their relative importance seems limited though. The number of regional citations of a public patent is very low and only a small fraction of all public patent applications result from a collaboration with a firm. The third channel is, however, suggested to be sizable and seems (compared to the other channels) to be in particular relevant for low R\&D intensity firms. Given that the last transmission channel is, however, difficult to capture, our results should be interpreted with some caution.

Using an IV strategy that exploits variation in lagged institutional funding of research institutes, we find evidence for substantial local knowledge spillovers of public R\&D. One additional public patent in the median county generates roughly 3 additional corporate patents if we assume our IV estimates to be unbiased. This suggests public costs of 1.4 million EURO per additional created corporate patent. Since we do not find evidence for less $R \& D$ in other regions by firms that benefit from local public $R \& D$ in one region, our result indicates that local public $R \& D$ is a cost-efficient firm R\&D support strategy. Moreover, our IV results are in line with the results of the transmission channel analysis as mainly low R\&D intensity firms respond to local public R\&D. While this seems conclusive, it should be stressed 
that our instrument, the 4-year lagged institutional funding, may not fully remove a potential omitted variable and reverse causality bias.

We believe that at least two conclusions can be drawn from our work. First, the German firm R\&D support strategy, which relied dominantly on public R\&D carried out by research institutes over our sample period, seems to be a successful one. If German firms are similar to, for example, US or UK firms, our result suggests that public $R \& D$ leads to more firm patent applications at the same public costs than using $R \& D$ tax credits to stimulate firm R\&D. Second, public R\&D seems to impact in particular $R \& D$ by local low $R \& D$ intensity (in other words small) firms. Since direct subsidies also impact in particular small firm R\&D (Lach, 2002; Hyytinen and Toivanen, 2005; González et al., 2005; Bronzini and Iachini, 2014; Howell, 2017), potentially due to alleviating financing constraints, our result suggests that nonspecific knowledge spillovers may be very influential as they allow firms to focus on innovation strategies that are more likely to be successful. 
Table 7: Results for Residing in a Location with Public Patents

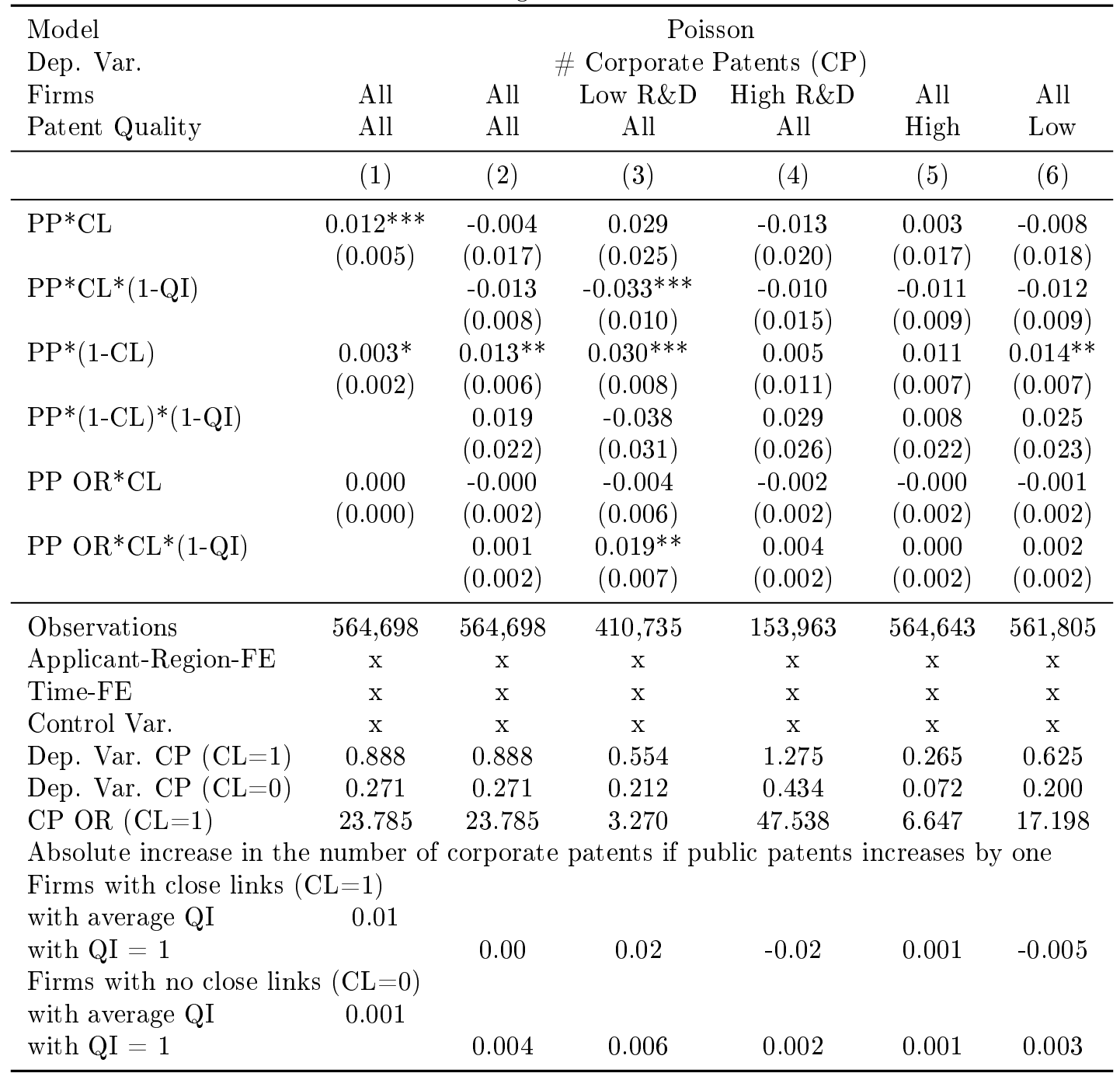

Notes: Table shows point estimates of Poisson model for the impact of residing in a location with public patents on the number of corporate patent applications (applicant and region-weighted). PP stands for the number of public patent applications, QI stands for quality index, CL for close links to a public institution and OR for other regions. All regressions include time and applicant-region fixed effects as well as the control variables described in the text. Col. (1) shows the baseline specification. Col. (2) accounts for the quality of public patents. Col. (3) includes only low R\&D intensity firms (less than 5 patent applications between 1995 and 1999 ) and col. (4) only high R\&D intensity firms. In col. (5) the dependent variable is the number of high quality corporate patents (sum over corporate patents multiplied with the quality index) and in col. (6) the number of low quality corporate patents (sum over corporate patents multiplied with 1 less quality index). The quality index is based on the number of patent classes a patent is filed for. The absolute increase in the number of corporate patents if the number of public patents increases by one is calculated by multiplying the PP coefficient with the mean of the dependent variable (shown in the bottom of the Table as well). Robust standard errors in parenthesis. ***,*** denote significance at the 10, 5 and $1 \%$ level. Source: Authors' calculation based on INKAR, OECD RegPAT and Citation database, 2000-2010. 
Table 8: Descriptive Statistics for County Level Estimation Sample

\begin{tabular}{lccccc}
\hline & Mean & P25 & Median & P75 & SD \\
\hline \# Corporate patents & 63.86 & 13.39 & 32.73 & 79.35 & 96.85 \\
\# Public patents & 2.02 & 0.00 & 0.39 & 1.58 & 5.63 \\
\# University patents & 0.67 & 0.00 & 0.00 & 0.50 & 1.99 \\
\# Institute patents & 1.35 & 0.00 & 0.17 & 0.91 & 4.06 \\
Population in 1,000 & 202 & 106 & 148 & 239 & 231 \\
Share skilled employees & 4.03 & 2.10 & 3.00 & 4.70 & 3.23 \\
Share unskilled employees & 7.67 & 5.20 & 7.30 & 9.30 & 3.36 \\
Students per 1,000 capita & 27.83 & 0.00 & 0.70 & 36.60 & 50.19 \\
Unemployment rate & 7.04 & 4.50 & 6.20 & 8.90 & 3.37 \\
Property tax multiplier & 350 & 313 & 343 & 390 & 77 \\
Business tax multiplier & 359 & 329 & 349 & 399 & 61 \\
Manufacturing employment in 1,000 & 37.75 & 16.51 & 26.77 & 46.14 & 33.46 \\
Share of manufacturing employment & 0.42 & 0.30 & 0.39 & 0.52 & 0.17 \\
Close to Luxembourg & 0.25 & 0.00 & 0.00 & 0.00 & 0.43 \\
Close to Belgium or the Netherlands & 0.34 & 0.00 & 0.00 & 1.00 & 0.47 \\
\hline Observations & 3,216 & & & & \\
\hline
\end{tabular}

Notes: Table reports descriptive statistics for our county level estimation sample. Property tax and business tax multiplier are municipality-population weighted. Source: Authors' calculation based on INKAR and OECD RegPAT database, 2003-2010. 
Table 9: IV Results

\begin{tabular}{|c|c|c|c|c|c|}
\hline \multirow{3}{*}{$\begin{array}{l}\text { Model } \\
\text { Dep. Var. }\end{array}$} & OLS & IV & OLS & IV & IV \\
\hline & \multicolumn{5}{|c|}{$\ln (\#$ Corporate Patents $(\mathrm{CP}))$} \\
\hline & (1) & & & (4) & $(5)$ \\
\hline \multirow[t]{2}{*}{ \# Public patents } & $0.004^{* *}$ & 0.054 & 0.005 & $0.101^{*}$ & $0.115^{* *}$ \\
\hline & $(0.002)$ & $(0.033)$ & $(0.004)$ & $(0.052)$ & $(0.057)$ \\
\hline \multirow[t]{2}{*}{ \# Public patents, sqrd. } & & & -0.000 & $-0.002^{*}$ & $-0.003 * *$ \\
\hline & & & $(0.000)$ & $(0.001)$ & $(0.001)$ \\
\hline \multirow[t]{2}{*}{ \# Public patents * Pop } & & & & & $0.073^{* *}$ \\
\hline & & & & & $(0.034)$ \\
\hline Observations & 3,212 & 3,212 & 3,212 & 3,212 & 3,212 \\
\hline Region-FE & $\mathrm{x}$ & $\mathrm{x}$ & $\mathrm{x}$ & $\mathrm{x}$ & $\mathrm{x}$ \\
\hline Time-FE & $\mathrm{x}$ & $\mathrm{x}$ & $\mathrm{x}$ & $\mathrm{x}$ & $\mathrm{x}$ \\
\hline Control Variables & $\mathrm{x}$ & $\mathrm{x}$ & $\mathrm{x}$ & $\mathrm{x}$ & $\mathrm{x}$ \\
\hline P-value Underidend. & & 0.002 & & 0.027 & 0.039 \\
\hline F-Stat. Weak ident. & & 15 & & 9 & 8 \\
\hline Dep. Var. CP & 81.158 & 81.158 & 81.158 & 81.158 & 81.158 \\
\hline \multicolumn{6}{|l|}{ Point Estimate First Stage } \\
\hline \multirow[t]{2}{*}{ L4.ln(Inst. Funding) } & & $1.687^{* * *}$ & & $-23.673^{* *}$ & -17.764 \\
\hline & & $(0.438)$ & & $(11.597)$ & $(11.218)$ \\
\hline \multirow[t]{2}{*}{ L4.ln(Inst. Funding), sqrd. } & & & & $0.867^{* *}$ & 0.608 \\
\hline & & & & $(0.396)$ & $(0.412)$ \\
\hline IV RESET 2nd Polynomial p & & 0.313 & & 0.680 & \\
\hline IV RESET 3rd Polynomial p & & 0.044 & & 0.890 & \\
\hline
\end{tabular}

Notes: Table shows estimated coefficients for the impact of the number of public patent applications in a county on the number of firm patent applications in the same county. All regressions include a full set of county as well as time-fixed effects. The dependent variable is (ln) number of firm patent applications. In col. (1) and (2) we only include the linear number of public patents and in col. (3) to (5) also the number of public patents squared. In col. (5) we additionally include an interaction effect between the number of public patents with the population in 2002 in million. In col. (2), (4) and (5) we address the potential endogeneity of public patent applications using an IV approach. The excluded instrument in col. (2) is the 4 -year lagged (ln) institutional funding for Fraunhofer and Leibniz institutes and in col. (4) and (5) the 4-year lagged (ln) institutional funding, linear and squared. In col. (5) we additionally use 4-year lagged (ln) institutional funding interacted with population in 2002. Robust standard errors in parentheses. *,**,*** denote statistical significance at the 10,5 and 1\% level. Source: Authors' calculation based on INKAR and OECD RegPAT database, 2003-2010. 
Table 10: IV Results: Heterogeneity in the Impact of Public R\&D

\begin{tabular}{lcccccc}
\hline Model & \multicolumn{5}{c}{$\ln (\#$ Corporate Patents (CP)) } \\
$\begin{array}{l}\text { Dep. Var. } \\
\text { Firms }\end{array}$ & \multicolumn{5}{c}{ Low R\&D } & High R\&D \\
Patent Quality & All & High & Low & All & High & Low \\
\hline & $(1)$ & $(2)$ & $(3)$ & $(4)$ & $(5)$ & $(6)$ \\
\hline \# Public patents & $0.198^{* *}$ & $0.235^{* *}$ & $0.194^{*}$ & -0.116 & -0.109 & -0.117 \\
& $(0.091)$ & $(0.098)$ & $(0.103)$ & $(0.124)$ & $(0.163)$ & $(0.124)$ \\
\# Public patents, sqrd. & $-0.003^{* *}$ & $-0.004^{* *}$ & $-0.003^{*}$ & 0.002 & 0.002 & 0.002 \\
& $(0.001)$ & $(0.002)$ & $(0.001)$ & $(0.002)$ & $(0.003)$ & $(0.002)$ \\
\hline Observations & 3,149 & 3,149 & 3,149 & 3,035 & 3,035 & 3,033 \\
County-FE & $\mathrm{x}$ & $\mathrm{x}$ & $\mathrm{x}$ & $\mathrm{x}$ & $\mathrm{x}$ & $\mathrm{x}$ \\
Time-FE & $\mathrm{x}$ & $\mathrm{x}$ & $\mathrm{x}$ & $\mathrm{x}$ & $\mathrm{x}$ & $\mathrm{x}$ \\
Control Variables & $\mathrm{x}$ & $\mathrm{x}$ & $\mathrm{x}$ & $\mathrm{x}$ & $\mathrm{x}$ & $\mathrm{x}$ \\
P-value Underidend. & 0.028 & 0.028 & 0.028 & 0.028 & 0.028 & 0.028 \\
F-Stat. Weak ident. & 9 & 9 & 9 & 8 & 8 & 8 \\
Dep. Var CP (PP $>0)$ & 35.670 & 8.743 & 26.915 & 40.684 & 10.763 & 29.929 \\
\hline
\end{tabular}

Notes: Table shows estimated coefficients of the impact of the number of public patent applications in a county on the number of corporate patent applications. All regressions include a full set of county as well as time-fixed effects and our set of control variables. Further, all columns show the results of the 2SLS estimation using 4-year lagged (ln) institutional funding for Fraunhofer and Leibniz institute, linear and squared, as excluded instruments. The dependent variable is in col. (1) (ln) number of corporate patent applications by low R\&D intensity firms, in col. (2) (ln) number of high quality corporate patent applications by low R\&D intensity firms, in col. (3) (ln) number of low quality corporate patent applications by low R\&D intensity firms. The dependent variable is in col. (4) (ln) number of corporate patent application by high R\&D intensity firms, in col. (5) (ln) number of high quality corporate patent applications by high R\&D intensity firms and in col. (6) (ln) number of low quality corporate patent applications by high R\&D intensity firms. Low R\&D intensity firms are firms that filed less than 5 patent applications between 1995 and 1999. Patent quality is based on patent scope (the number of IPC classes a patent is filed for). Robust standard errors in parentheses. ${ }^{*}, * *, * * *$ denote statistical significance at the 10, 5 and $1 \%$ level. Source: Authors' calculation based on INKAR and OECD RegPAT database, 2003-2010. 


\section{Acknowledgments}

We thank Adam Jaffe (the editor), three anonymous referees, Steve Bond, Laurie Ciaramella (discussant), Mike Devereux, Irem Guceri, Nadine Riedel, Eddy Tam and Jing Xing as well as seminar participants at Oxford University, at the ZEW Public Finance conference 2018 in Mannheim and at the IIPF in Tampere for valuable

comments. Further, we would like to thank Julian Schlimme for research assistance, Martin Thum from the Fraunhofer Society and Adelheid Flemm from the Max Planck Society and their colleagues for providing us with data on Fraunhofer and Max Planck institutes and Andreas Bliemeister from the Leibniz Society as well as the relevant employees of the Helmholtz centers for supporting our data collection process for the Leibniz and Helmholtz institutes.

This research was partially funded by the German Research Foundation (SI 2050/11). 


\section{References}

Abel, J. R. and Deitz, R. (2011). Do colleges and universities increase their region's human capital? Journal of Economic Geography, 12(3):667-691.

Abramovsky, L., Harrison, R., and Simpson, H. (2007). University research and the location of business R\&D. The Economic Journal, 117(519):114-141.

Acs, Z. J., Audretsch, D. B., and Feldman, M. P. (1994). R\&D spillovers and recipient firm size. The Review of Economics and Statistics, pages 336-340.

Alcacer, J. and Gittelman, M. (2006). Patent citations as a measure of knowledge flows: The influence of examiner citations. The Review of Economics and Statistics, $88(4): 774-779$.

Almeida, P. and Kogut, B. (1999). Localization of knowledge and the mobility of engineers in regional networks. Management science, 45(7):905-917.

Alstadsaeter, A., Barrios, S., Nicodeme, G., Skonieczna, A. M., and Vezzani, A. (2018). Patent boxes design, patents location, and local R\&D. Economic Policy, 33(93):131-177.

Andersson, R., Quigley, J. M., and Wilhelmsson, M. (2009). Urbanization, productivity, and innovation: Evidence from investment in higher education. Journal of Urban Economics, 66(1):2-15.

Ankrah, S. and AL-Tabbaa, O. (2015). Universities-industry collaboration: A systematic review. Scandinavian Journal of Management, 31(3):387 - 408.

Arrow, K. J. (1962). The economic implications of learning by doing. The Review of Economic Studies, 29(3):155-173.

Audretsch, D. B. and Feldman, M. P. (1996). R\&D spillovers and the geography of innovation and production. The American Economic Review, 86(3):630-640.

Belenzon, S. and Schankerman, M. (2013). Spreading the word: Geography, policy, and knowledge spillovers. Review of Economics and Statistics, 95(3):884-903. 
Bercovitz, J. and Feldman, M. (2006). Entrepreneurial universities and technology transfer: A conceptual framework for understanding knowledge-based economic development. The Journal of Technology Transfer, 31(1):175-188.

Bloom, N., Schankerman, M., and Van Reenen, J. (2013). Identifying technology spillovers and product market rivalry. Econometrica, 81(4):1347-1393.

Bound, J., Cummins, C., Griliches, Z., Hall, B. H., and Jaffe, A. B. (1984). Who does R\&D and who patents? In Griliches, Z., editor, R\&D, patents and productivity, pages 21-54. University of Chicago Press.

Branstetter, L. (2005). Exploring the link between academic science and industrial innovation. Annals of Economics and Statistics, 79(80):119-142.

Branstetter, L. G. and Sakakibara, M. (2002). When do research consortia work well and why? Evidence from Japanese panel data. The American Economic Review, 92(1):143-159.

Bronzini, R. and Iachini, E. (2014). Are incentives for R\&D effective? Evidence from a regression discontinuity approach. American Economic Journal: Economic Policy, 6(4):100-134.

Cassiman, B., Veugelers, R., and Arts, S. (2012). How to capture value from linking to science-driven basic research: Boundary crossing inventors and partnerships. In 2012 IEEE International Conference on Management of Innovation Technology (ICMIT), pages 619-623.

Cassiman, B., Veugelers, R., and Zuniga, P. (2008). In search of performance effects of (in) direct industry science links. Industrial and Corporate Change, 17(4):611646.

David, P. A., Hall, B. H., and Toole, A. A. (2000). Is public R\&D a complement or substitute for private R\&D? A review of the econometric evidence. Research Policy, 29(4):497 - 529. 
Dechezlepretre, A., Einiö, E., Martin, R., Nguyen, K.-T., and Van Reenen, J. (2016). Do tax incentives for research increase firm innovation? An RD design for R\&D. Working Paper 22405, National Bureau of Economic Research.

Feldman, M. P. and Kogler, D. F. (2010). Chapter 8 - Stylized facts in the geography of innovation. In Hall, B. H. and Rosenberg, N., editors, Handbook of The Economics of Innovation, Vol. 1, volume 1 of Handbook of the Economics of Innovation, pages 381 - 410. North-Holland.

Foray, D. and Lissoni, F. (2010). Chapter 6 - University research and public-private interaction. In Hall, B. H. and Rosenberg, N., editors, Handbook of The Economics of Innovation, Vol. 1, volume 1 of Handbook of the Economics of Innovation, pages 275 - 314. North-Holland.

González, X., Jaumandreu, J., and Pazó, C. (2005). Barriers to innovation and subsidy effectiveness. RAND Journal of Economics, 36(4):930-950.

Griffith, R., Lee, S., and Van Reenen, J. (2011). Is distance dying at last? Falling home bias in fixed-effects models of patent citations. Quantitative Economics, $2(2): 211-249$.

Griliches, Z. (1998). Patent statistics as economic indicators: A survey. In $R \mathscr{E} D$ and Productivity: The Econometric Evidence, pages 287-343. National Bureau of Economic Research, Inc.

Guceri, I. (2018). Will the real R\&D employees please stand up? Effects of tax breaks on firm-level outcomes. International Tax and Public Finance, 25(1):1-63.

Guceri, I. and Liu, L. (2019). Effectiveness of fiscal incentives for R\&D: Quasiexperimental evidence. American Economic Journal: Economic Policy, 11(1):26691.

Hall, B. and Van Reenen, J. (2000). How effective are fiscal incentives for R\&D? A review of the evidence. Research Policy, 29(4-5):449-469. 
Harhoff, D., Scherer, F. M., and Vopel, K. (2003). Citations, family size, opposition and the value of patent rights. Research Policy, 32(8):1343-1363.

Hashem Pesaran, M. and Taylor, L. W. (1999). Diagnostics for IV regressions. Oxford Bulletin of Economics and Statistics, 61(2):255-281.

Howell, S. T. (2017). Financing innovation: Evidence from R\&D grants. The American Economic Review, 107(4):1136-64.

Hyytinen, A. and Toivanen, O. (2005). Do financial constraints hold back innovation and growth? Evidence on the role of public policy. Research Policy, 34(9):13851403.

Jaffe, A. B. (1989). Real effects of academic research. The American Economic Review, 79(5):957-970.

Jaffe, A. B., Trajtenberg, M., and Henderson, R. (1993). Geographic localization of knowledge spillovers as evidenced by patent citations. The Quarterly Journal of Economics, 108(3):577-598.

Kantor, S. and Whalley, A. (2014). Knowledge spillovers from research universities: Evidence from endowment value shocks. Review of Economics and Statistics, 96(1):171-188.

Lach, S. (2002). Do R\&D subsidies stimulate or displace private R\&D? Evidence from Israel. The Journal of Industrial Economics, 50(4):369-390.

Lanjouw, J. O. and Schankerman, M. (2001). Characteristics of patent litigation: A window on competition. The RAND Journal of Economics, 32(1):129-151.

Lerner, J. (1994). The importance of patent scope: An empirical analysis. The RAND Journal of Economics, 25(2):319-333.

Link, A. N. and Rees, J. (1990). Firm size, university based research, and the returns to R\&D. Small Business Economics, 2(1):25-31. 
Lokshin, B. and Mohnen, P. (2012). How effective are level-based R\&D tax credits? Evidence from the Netherlands. Applied Economics, 44(12):1527-1538.

Lychagin, S., Pinkse, J., Slade, M. E., and Reenen, J. V. (2016). Spillovers in space: Does geography matter? The Journal of Industrial Economics, 64(2):295-335.

Maurseth, P. B. and Verspagen, B. (2002). Knowledge spillovers in Europe: A patent citations analysis. Scandinavian Journal of Economics, 104(4):531-545.

Michel, J. and Bettels, B. (2001). Patent citation analysis: A closer look at the basic input data from patent search reports. Scientometrics, 51(1):185-201.

Mulkay, B. and Mairesse, J. (2013). The R\&D tax credit in France: Assessment and ex ante evaluation of the 2008 reform. Oxford Economic Papers, 65(3):746-766.

Narin, F., Hamilton, K. S., and Olivastro, D. (1997). The increasing linkage between US technology and public science. Research Policy, 26(3):317-330.

Nelson, R. R. (1959). The simple economics of basic scientific research. Journal of Political Economy, 67(3):297-306.

OECD (2015). Measuring the technological and economic value of patents. Chapter 2 in Enquiries into intellectual property's economic impact.

Rao, N. (2016). Do tax credits stimulate R\&D spending? The effect of the R\&D tax credit in its first decade. Journal of Public Economics, 140:1-12.

Rybnicek, R. and Königsgruber, R. (2019). What makes industry-university collaboration succeed? A systematic review of the literature. Journal of Business Economics, 89(2):221-250.

Scandura, A. (2016). University-industry collaboration and firms' R\&D effort. Research Policy, 45(9):1907 - 1922.

Scherer, F. M. (1983). The propensity to patent. International Journal of Industrial Organization, 1(1):107-128. 
Trajtenberg, M., Henderson, R., and Jaffe, A. (1997). University versus corporate patents: A window on the basicness of invention. Economics of Innovation and New Technology, 5(1):19-50.

Van Looy, B., Callaert, J., and Debackere, K. (2006). Publication and patent behavior of academic researchers: Conflicting, reinforcing or merely co-existing? Research Policy, 35(4):596-608.

von Wartburg, I., Teichert, T., and Rost, K. (2005). Inventive progress measured by multi-stage patent citation analysis. Research Policy, 34(10):1591 - 1607.

Walsh, J. P., Lee, Y.-N., and Nagaoka, S. (2016). Openness and innovation in the US: Collaboration form, idea generation and implementation. Research Policy, 45(8):1660 - 1671.

Webb, C., Dernis, H., Harhoff, D., and Hoisl, K. (2005). Analysing European and international patent citations.

Zúñiga-Vicente, J., Alonso-Borrego, C., Forcadell, F., and Galán, J. (2014). Assessing the effect of public subsidies on firm R\&D investment: A survey. Journal of Economic Surveys, 28(1):36-67. 


\section{Appendix A. Appendix: Additional Descriptive Statistics and Regres- sion Results}

Table A.1: Descriptive Statistics for Applicant-Region Level Estimation Samples

\begin{tabular}{lcccccc}
\hline Sample & \multicolumn{2}{c}{ JV } & \multicolumn{2}{c}{ CITED } & \multicolumn{2}{c}{ Public Patent } \\
& Mean & Median & Mean & Median & Mean & Median \\
\hline \# Corporate patents & 0.51 & 0.00 & 0.51 & 0.00 & 0.29 & 0.00 \\
\# JV & 0.02 & 0.00 & 0.01 & 0.00 & 0.00 & 0.00 \\
\# CITED & 0.00 & 0.00 & 0.01 & 0.00 & 0.00 & 0.00 \\
\# Public patents & 4.78 & 1.02 & 4.52 & 1.00 & 5.24 & 1.03 \\
Population in 1,000 & 272 & 202 & 267 & 200 & 299 & 237 \\
Share skilled employees & 5.03 & 3.40 & 4.92 & 3.30 & 4.94 & 3.40 \\
Share unskilled employees & 8.49 & 8.10 & 8.46 & 8.10 & 8.61 & 8.30 \\
Students per 1,000 capita & 33.99 & 4.20 & 33.37 & 4.00 & 31.43 & 4.40 \\
Unemployment rate & 5.95 & 5.30 & 5.93 & 5.30 & 5.83 & 5.20 \\
Property tax multiplier & 357 & 344 & 358 & 343 & 359 & 344 \\
Business tax multiplier & 372 & 355 & 372 & 3543 & 3754 & 356 \\
Manufacturing empl. in 1,000 & 53.87 & 40.34 & 53.24 & 40.17 & 61.29 & 45.45 \\
Share of manufacturing empl. & 0.42 & 0.39 & 0.42 & 0.40 & 0.44 & 0.41 \\
Close to LUX & 0.34 & 0.00 & 0.31 & 0.00 & 0.33 & 0.00 \\
Close to BEL or NLD & 0.36 & 0.00 & 0.34 & 0.00 & 0.38 & 0.00 \\
\hline Observations & 73,395 & 89,251 & 564,698 \\
\hline
\end{tabular}

Notes: Table reports descriptive statistics for the three estimation samples for the transmission channels of knowledge spillovers of public R\&D. JV stands for joint venture between firms and public institutions and CITED for a local corporate patent citing a public patent. The JV sample only includes applicants that collaborated with a public institutions between 1995 and 2015. The CITED sample only includes applicants that cited at least one public patent. The Public Patent sample includes all applicantregion observations. Applicant-region observations are only included if at least one corporate patent has been filed for this applicant-region combination between 1995 and 2015. The sample period is 2000 to 2010. Property tax and business tax multiplier are municipality-population weighted. Source: Authors' calculation based on INKAR and OECD RegPAT and Citation database, 2000-2010. 
Table A.2: Robustness IV Results

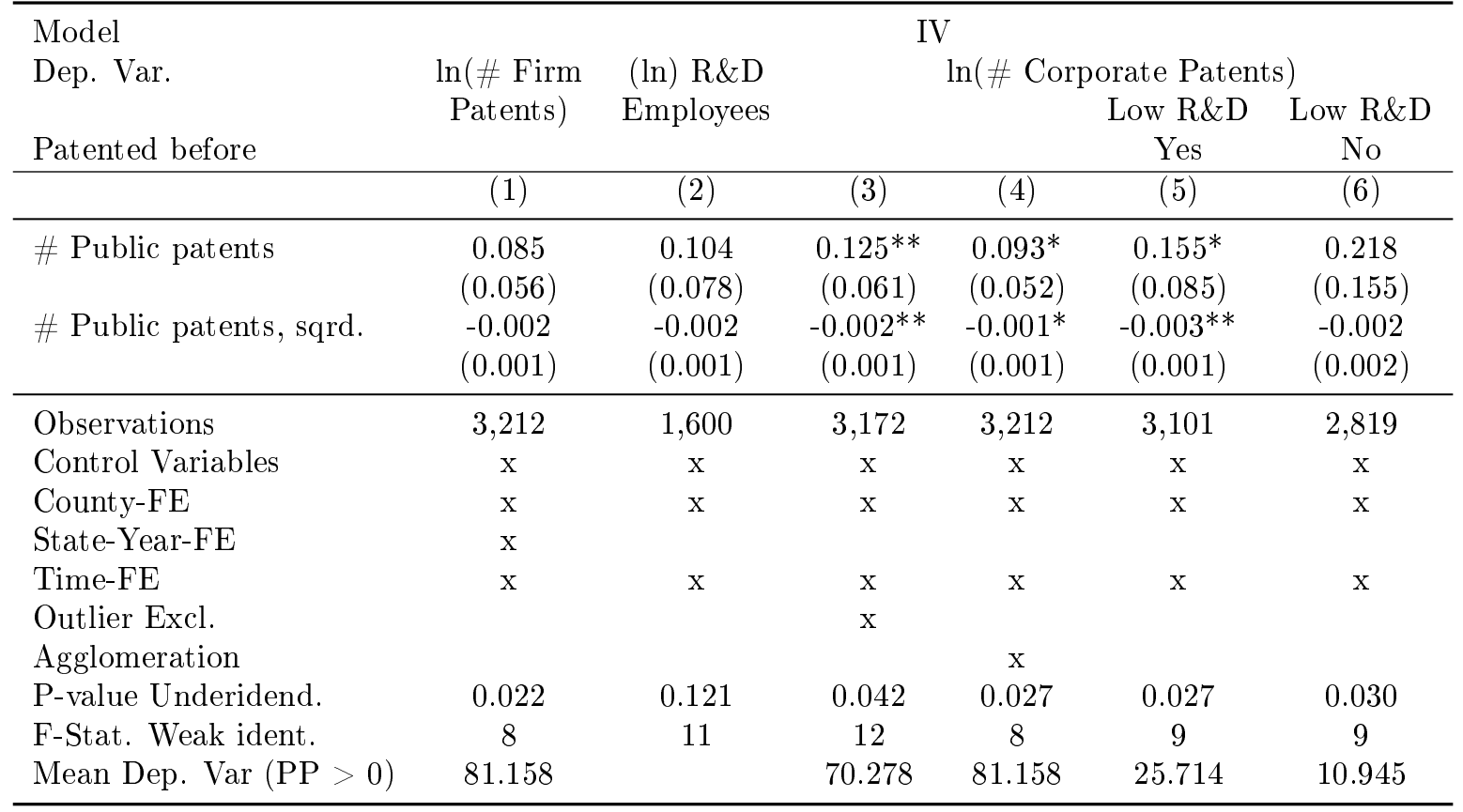

Notes: Table shows estimated coefficients of the sensitivity analysis for the impact of the number of public patent applications in a county on the number of firm patent applications in the same county. All regressions include a full set of county as well as time-fixed effects and our set of control variables. Further, all columns show the results of the 2SLS estimation using 4-year lagged (ln) institutional funding for Fraunhofer and Leibniz institutes, linear and squared, as excluded instruments. In col. (1) we additionally include state-year fixed effects. In col. (2) we use (ln) number of firm R\&D employees as dependent variable. In col. (3) we address a potential overdispersion of the data by excluding regions with a number of firm patents in the top $1 \%$ of the distribution. In col. (4) we additionally control for the number of corporate patents in a region between 1991 and 2000 interacted with year dummies to account for the impact of agglomeration economies. In col. (5) we only use the number of patents by firms that filed between 1 and 5 patent applications between 1995 and 1999 as dependent variable and in col. (6) we only use the number of patents by firms that did not file patent applications between 1995 and 1999 as dependent variable. Robust standard errors in parentheses. ${ }^{*}, * *, * * *$ denote statistical significance at the 10,5 and $1 \%$ level. Source: Authors' calculation based on INKAR and OECD RegPAT database, 2003-2010. 
Table A.3: Results for Control Variables in Table 10

\begin{tabular}{|c|c|c|c|c|c|c|}
\hline \multirow{3}{*}{$\begin{array}{l}\text { Model } \\
\text { Dep. Var. } \\
\text { Firms } \\
\text { Patents Quality }\end{array}$} & \multicolumn{6}{|c|}{$\begin{array}{c}\text { IV } \\
\text { \# Corporate Patents }\end{array}$} \\
\hline & \multicolumn{3}{|c|}{ Low R\&D Intensity } & \multicolumn{3}{|c|}{ High R\&D Intensity } \\
\hline & All & High & Low & All & High & Low \\
\hline & (1) & $(2)$ & (3) & (4) & (5) & (6) \\
\hline Close to Lux * $\mathrm{D}(>2006)$ & $\begin{array}{c}-0.001 \\
(0.041)\end{array}$ & $\begin{array}{l}-0.020 \\
(0.049)\end{array}$ & $\begin{array}{c}0.002 \\
(0.042)\end{array}$ & $\begin{array}{c}0.095^{* *} \\
(0.046)\end{array}$ & $\begin{array}{r}0.104^{* *} \\
(0.049)\end{array}$ & $\begin{array}{l}0.091^{*} \\
(0.048)\end{array}$ \\
\hline Close to NLD, BEL* $\mathrm{D}(>2007)$ & $\begin{array}{l}-0.042 \\
(0.041)\end{array}$ & $\begin{array}{l}-0.014 \\
(0.049)\end{array}$ & $\begin{array}{l}-0.047 \\
(0.042)\end{array}$ & $\begin{array}{l}-0.055 \\
(0.045)\end{array}$ & $\begin{array}{l}-0.085^{*} \\
(0.049)\end{array}$ & $\begin{array}{l}-0.036 \\
(0.047)\end{array}$ \\
\hline Population & $\begin{array}{c}0.001 \\
(0.006)\end{array}$ & $\begin{array}{c}0.002 \\
(0.008)\end{array}$ & $\begin{array}{c}0.000 \\
(0.006)\end{array}$ & $\begin{array}{l}-0.006 \\
(0.006)\end{array}$ & $\begin{array}{l}-0.007 \\
(0.006)\end{array}$ & $\begin{array}{l}-0.006 \\
(0.007)\end{array}$ \\
\hline Property tax multiplier & $\begin{array}{c}-0.001 * \\
(0.001)\end{array}$ & $\begin{array}{c}-0.002 \\
(0.001)\end{array}$ & $\begin{array}{l}-0.002^{*} \\
(0.001)\end{array}$ & $\begin{array}{c}0.000 \\
(0.001)\end{array}$ & $\begin{array}{c}0.000 \\
(0.001)\end{array}$ & $\begin{array}{c}0.000 \\
(0.001)\end{array}$ \\
\hline Business tax multiplier & $\begin{array}{c}0.004^{* *} \\
(0.002)\end{array}$ & $\begin{array}{c}0.005^{* *} \\
(0.002)\end{array}$ & $\begin{array}{c}0.004^{* *} \\
(0.002)\end{array}$ & $\begin{array}{c}0.001 \\
(0.002)\end{array}$ & $\begin{array}{c}0.001 \\
(0.003)\end{array}$ & $\begin{array}{c}0.001 \\
(0.002)\end{array}$ \\
\hline Students per 1.000 capita & $\begin{array}{c}0.003 \\
(0.002)\end{array}$ & $\begin{array}{c}0.004 \\
(0.002)\end{array}$ & $\begin{array}{c}0.003 \\
(0.002)\end{array}$ & $\begin{array}{l}-0.002 \\
(0.002)\end{array}$ & $\begin{array}{l}-0.002 \\
(0.003)\end{array}$ & $\begin{array}{l}-0.002 \\
(0.002)\end{array}$ \\
\hline Share unskilled employees & $\begin{array}{r}-0.057^{*} \\
(0.032)\end{array}$ & $\begin{array}{c}-0.061^{*} \\
(0.034)\end{array}$ & $\begin{array}{c}-0.058^{*} \\
(0.033)\end{array}$ & $\begin{array}{l}-0.006 \\
(0.029)\end{array}$ & $\begin{array}{l}-0.021 \\
(0.034)\end{array}$ & $\begin{array}{c}0.003 \\
(0.029)\end{array}$ \\
\hline Share skilled employees & $\begin{array}{l}-0.059 \\
(0.075)\end{array}$ & $\begin{array}{l}-0.046 \\
(0.084)\end{array}$ & $\begin{array}{l}-0.070 \\
(0.081)\end{array}$ & $\begin{array}{c}0.072 \\
(0.080)\end{array}$ & $\begin{array}{c}0.066 \\
(0.097)\end{array}$ & $\begin{array}{c}0.071 \\
(0.080)\end{array}$ \\
\hline ln Manufacturing empl. & $\begin{array}{c}1.292^{* * *} \\
(0.474)\end{array}$ & $\begin{array}{l}1.344^{* *} \\
(0.574)\end{array}$ & $\begin{array}{l}1.210^{* *} \\
(0.492)\end{array}$ & $\begin{array}{c}0.327 \\
(0.488)\end{array}$ & $\begin{array}{l}0.942^{*} \\
(0.541)\end{array}$ & $\begin{array}{c}0.011 \\
(0.500)\end{array}$ \\
\hline Share manufacturing empl. & $\begin{array}{l}-2.051 \\
(1.365)\end{array}$ & $\begin{array}{l}-1.527 \\
(1.603)\end{array}$ & $\begin{array}{l}-2.114 \\
(1.421)\end{array}$ & $\begin{array}{c}0.807 \\
(1.386)\end{array}$ & $\begin{array}{l}-0.530 \\
(1.570)\end{array}$ & $\begin{array}{c}1.440 \\
(1.412)\end{array}$ \\
\hline Unemployment rate & $\begin{array}{l}-0.020 \\
(0.018)\end{array}$ & $\begin{array}{l}-0.011 \\
(0.021)\end{array}$ & $\begin{array}{l}-0.024 \\
(0.019)\end{array}$ & $\begin{array}{l}-0.026 \\
(0.022)\end{array}$ & $\begin{array}{l}-0.022 \\
(0.024)\end{array}$ & $\begin{array}{l}-0.026 \\
(0.023)\end{array}$ \\
\hline $\begin{array}{l}\text { Observations } \\
\text { County FE }\end{array}$ & $\begin{array}{c}3,149 \\
\times\end{array}$ & $\begin{array}{c}3,149 \\
\times\end{array}$ & $\begin{array}{c}3,149 \\
\mathrm{x}\end{array}$ & $\begin{array}{c}3,035 \\
\mathrm{x}\end{array}$ & $\begin{array}{c}3,035 \\
\mathrm{x}\end{array}$ & 3,033 \\
\hline
\end{tabular}

Notes: Table shows estimated coefficients for the control variables of the specification reported in Table 10. Robust standard errors in parentheses. ${ }^{*},{ }^{*},{ }^{* * *}$ denote statistical significance at the 10,5 and $1 \%$ level. Source: Authors' calculation based on INKAR and OECD RegPAT database, 2003-2010. 